\title{
An investigation on climate responsive design strategies of vernacular housing in Vietnam
}

\author{
Anh-Tuan Nguyen ${ }^{\mathrm{a}}$, Quoc-Bao Tran ${ }^{\mathrm{b}}$, Duc-Quang $\operatorname{Tran}^{\mathrm{c}}$, Sigrid Reiter ${ }^{\mathrm{a}}$ \\ ${ }^{a}$ LEMA, University of Liège, Bat. B52/3, Chemin des Chevreuils 1, 4000 Liège (Sart-Tilman), Belgium \\ ${ }^{b}$ Faculty of Architecture and Planning, National University of Civil Engineering, Viet Nam \\ ${ }^{c}$ Faculty of Civil Engineering, Danang University of Technology, Viet Nam
}

\begin{abstract}
Energy conservation issues and environmental problems in recent years have increased interest in traditional architecture which is well known for its energy saving designs. This paper thoroughly investigates vernacular housing designs and evaluates on the aspect of building physics. A new research methodology which is adapted to the natural and social context of Vietnam was proposed and applied. The process was carried out step by step, including: climate zoning, systematic analysis, in-situ survey and building simulations. The results of this study indicate that vernacular housing in Vietnam is creatively adapted to the local natural conditions and uses various climate responsive strategies. Through this study, the most frequently used strategies and their effectiveness were derived. The authors also found that under extreme weather conditions, traditional designs might not be sufficient to maintain indoor thermal comfort.
\end{abstract}

Keywords : Vernacular housing ; Climatic design strategies ; CFD ; Solar shading ; Thermal simulation

\section{Introduction}

In recent years, facing the risk of global warming and of the depletion of fossil fuels, reduction in energy consumption along with sustainable development is a priority for many countries, including Vietnam. Today, we generally acknowledge that the building sector consumes about one-third of the total energy consumption worldwide and this figure may vary according to building type and location. In 2010, the building sector in Vietnam occupied between $20 \%$ and $24 \%$ of the total national energy consumption and this portion is expected to increase significantly [1]. Reducing energy use, especially energy used by occupants of buildings, is an important issue in Vietnam as the country is constantly in the state of energy crisis. Research to reduce energy consumption in the building sector through climate responsive strategies without compromising human comfort is essential. Vernacular architecture is widely recognised as a practical, effective and popular solution.

Vernacular architecture is a term used to categorise methods of construction which use locally available resources to address the local needs [2]. Vernacular architecture results from long-term growth and is part of traditional popular culture; therefore vernacular architecture is considered well adapted to the natural and social conditions of a specific location in which it exists.

In Vietnam, many detailed studies have shown that Vietnamese vernacular architecture is multiform and valuable. Unfortunately, due to many fierce wars, the impact of state policies (for example the land reform from 1953 to 1956) and natural disasters, much vernacular architecture in Vietnam has been destroyed or has disappeared altogether. Today, those remaining are very modest in scale and form, but the architectural and environmental lessons that they provide are still considerable.

The principal purposes of this study were to: (1) search and discover the underlying climate responsive strategies conceived in vernacular architecture; (2) transform and recommend appropriate solutions for current design and construction, aiming towards sustainable development and (3) assess the importance of preserving the vernacular housing remaining in Vietnam.

Six old houses in rural and urban areas spread over the 3 regions of Vietnam, representing vernacular architecture, traditional architecture and old architecture, were thoroughly investigated to understand the climatic 
design strategies employed and their effectiveness in maintaining human comfort and health.

\section{Materials and methods}

To comprehensively and systematically review architectural strategies in Vietnam, both scientific methods and respect for the natural and social context was essential. Various approaches were employed in the literature. Dili et al. [3] used long-term in-situ measurement method to evaluate the thermal environment in a traditional building in Kerala, India. Cañas and Martín [4] employed statistical method to gather data about vernacular Spanish buildings and categorised them into different bioclimatic strategies based on their locations. By doing so, they found the most frequently used strategies which correspondenced to the building locations and local climate. Vissilia [5] conducted a study to evaluate a sustainable Greek vernacular settlement by using subsequent analysis, based on two major steps: (1) a study concerning the evolution of the built environment (typological analysis, site planning, construction materials and techniques), and (2) an evaluation of specific vernacular dwelling types and their response to climate, based on passive design principles. She has made it clear that the vernacular settlement demonstrates an economical use of local building resources, adapting to climatic conditions without using much energy and providing human comfort.

Manioğlu and Yılmaz [6] studied energy saving design strategies employed in ancient housing in Mardin, Turkey. They made a simplified thermal evaluation and comparison of a traditional house with a contemporary house by using in-situ measurement method and questionnaires which were carried out for 100 buildings. They found traditional houses performed better than their counterparts in providing human comfort and energy saving.

In an intensive study in Japan, Hiroshi et al. [7] researched four traditional farmhouses using both in-situ measurement and computer simulation on a model house. Their findings revealed that cooling technologies of traditional buildings, such as solar shading by thatched roof, earthen floor and natural ventilation et cetera are effective for interior cooling.

The territory of Vietnam stretches from the North to the South and along the country the complex social background differs. Based on these geographical and social characteristics and referring to all the abovementioned methods (in-situ measurement, statistical method, comparative study and computer simulation), this study proposes a new approach for analysing and evaluating vernacular dwellings in Vietnam in terms of building physics. This approach includes six subsequent steps as clearly described in Fig. 1. It is expected that both qualitative and quantitative analysis included in this method will reinforce the findings from this study.

Fig. 1. New approaches and steps proposed and applied in this research.

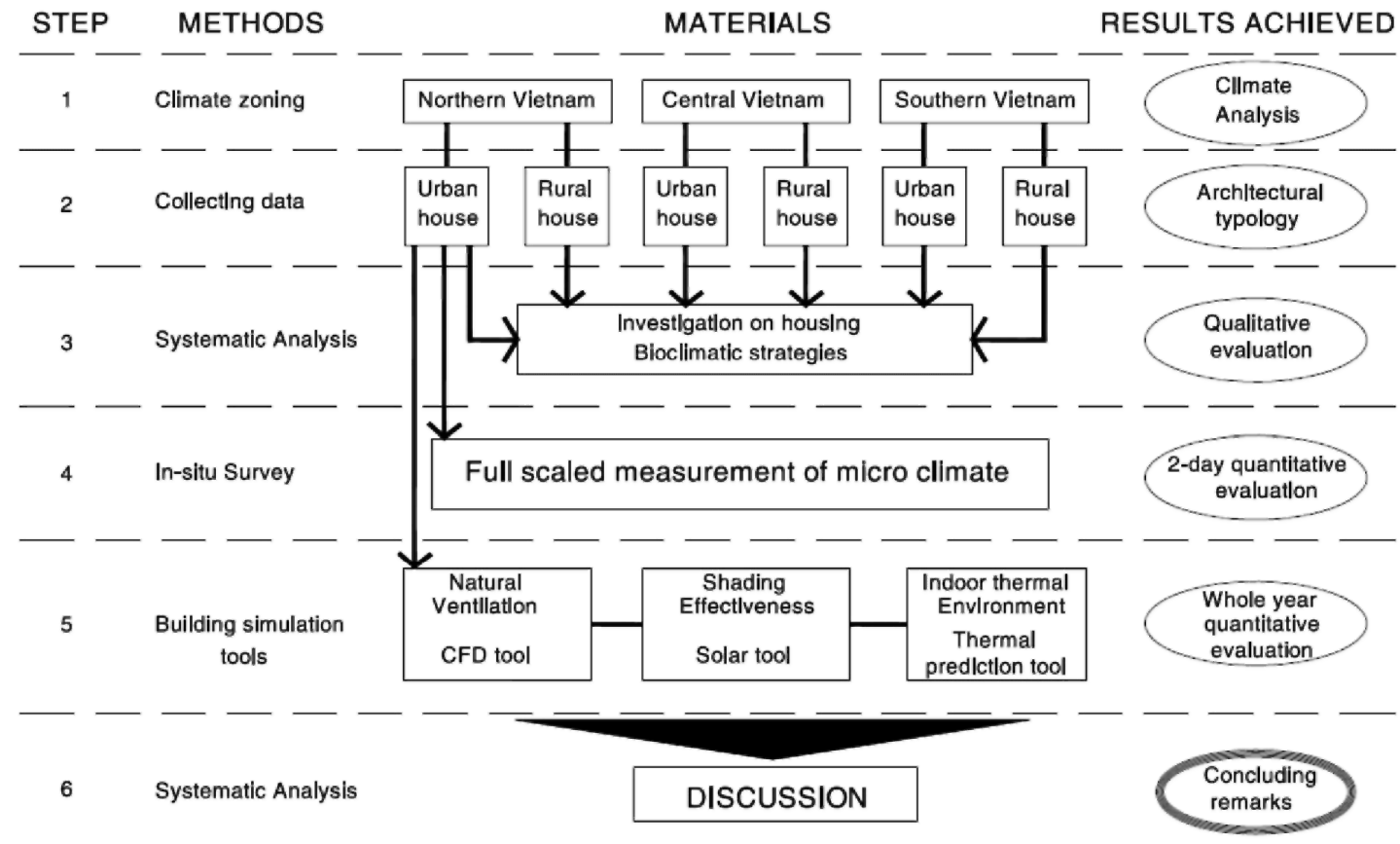


Fig. 2. The map of Vietnam which shows the selected sites of the present study.

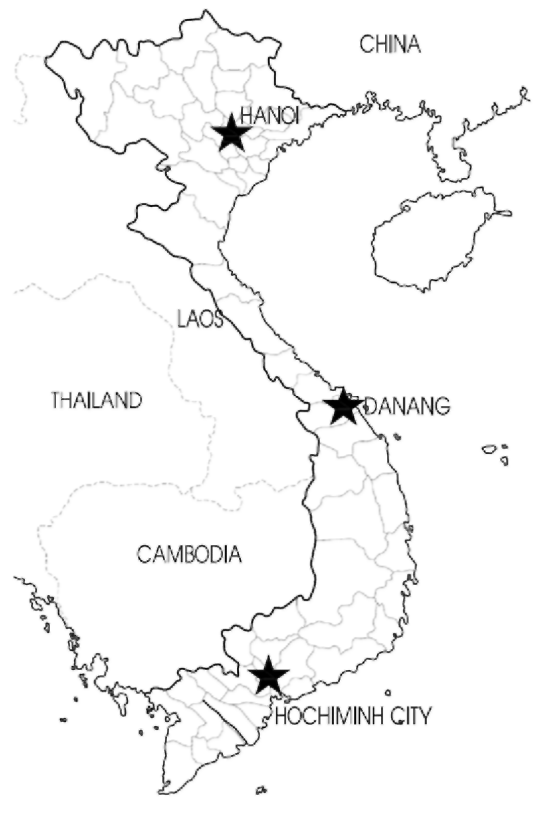

Fig. 3. Sun paths and climate data of three selected sites.
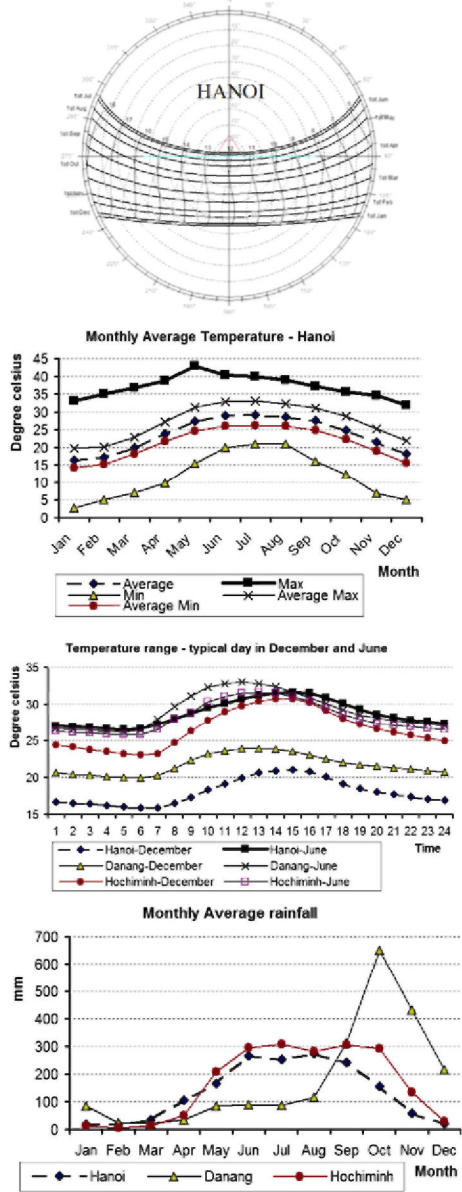

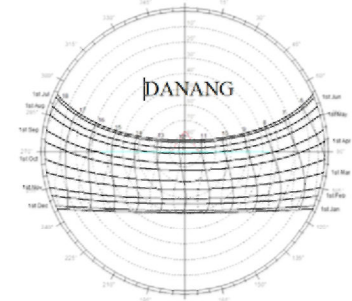

Monthly Average Temperature - Danang
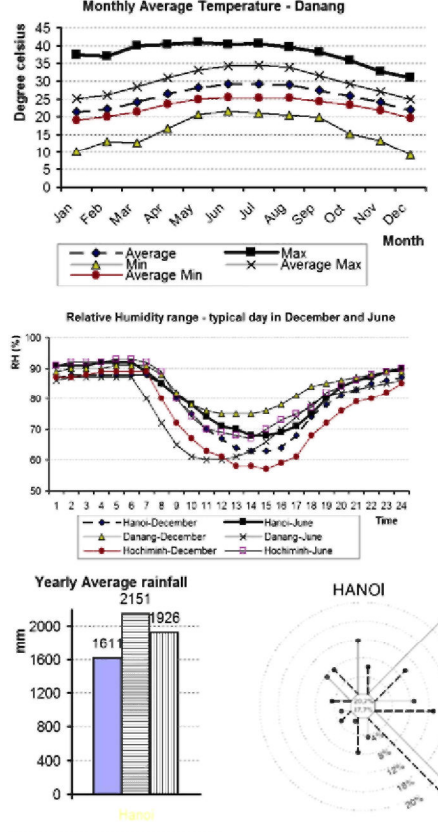

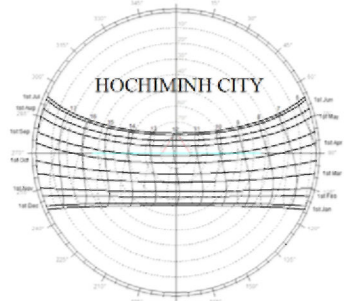

Monthly Average Temperature - Hochiminh
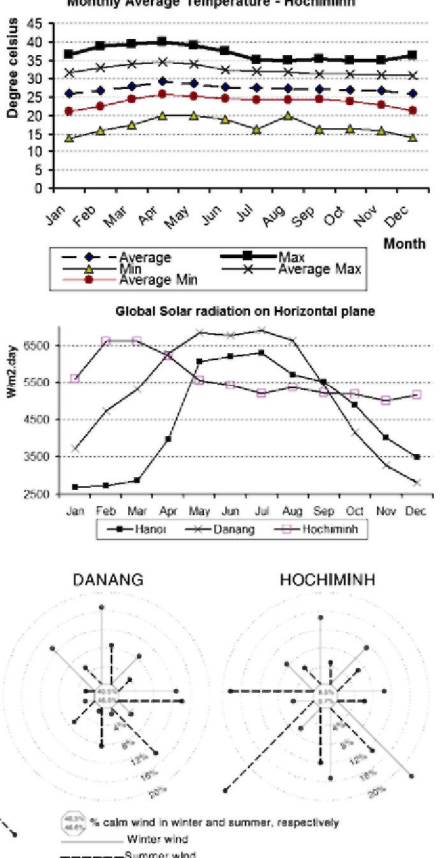
Fig. 4. Traditional life on boats affected the housing style of Viet people: (a) ancient boat and (b) ancient house found on Dong Son bronze drum 6th century BC; (c) current Viet communal house.

a

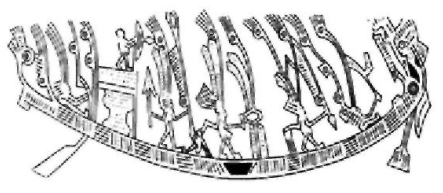

b

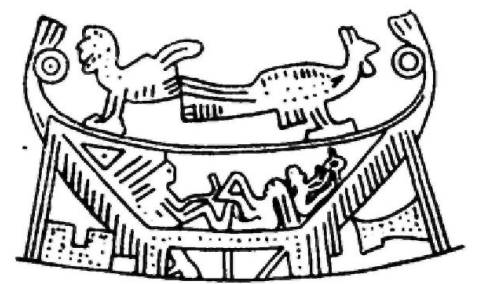

c

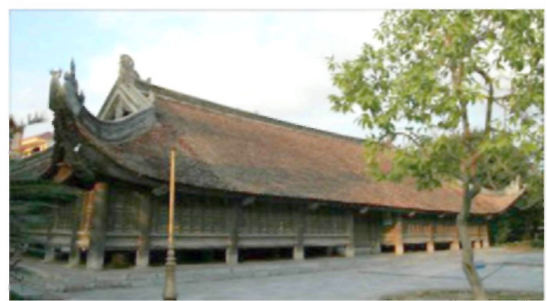

Fig. 5. Architectural details of selected houses: house A; house B; house C; House D; house E; house F (from left to right and upper to lower, respectively).
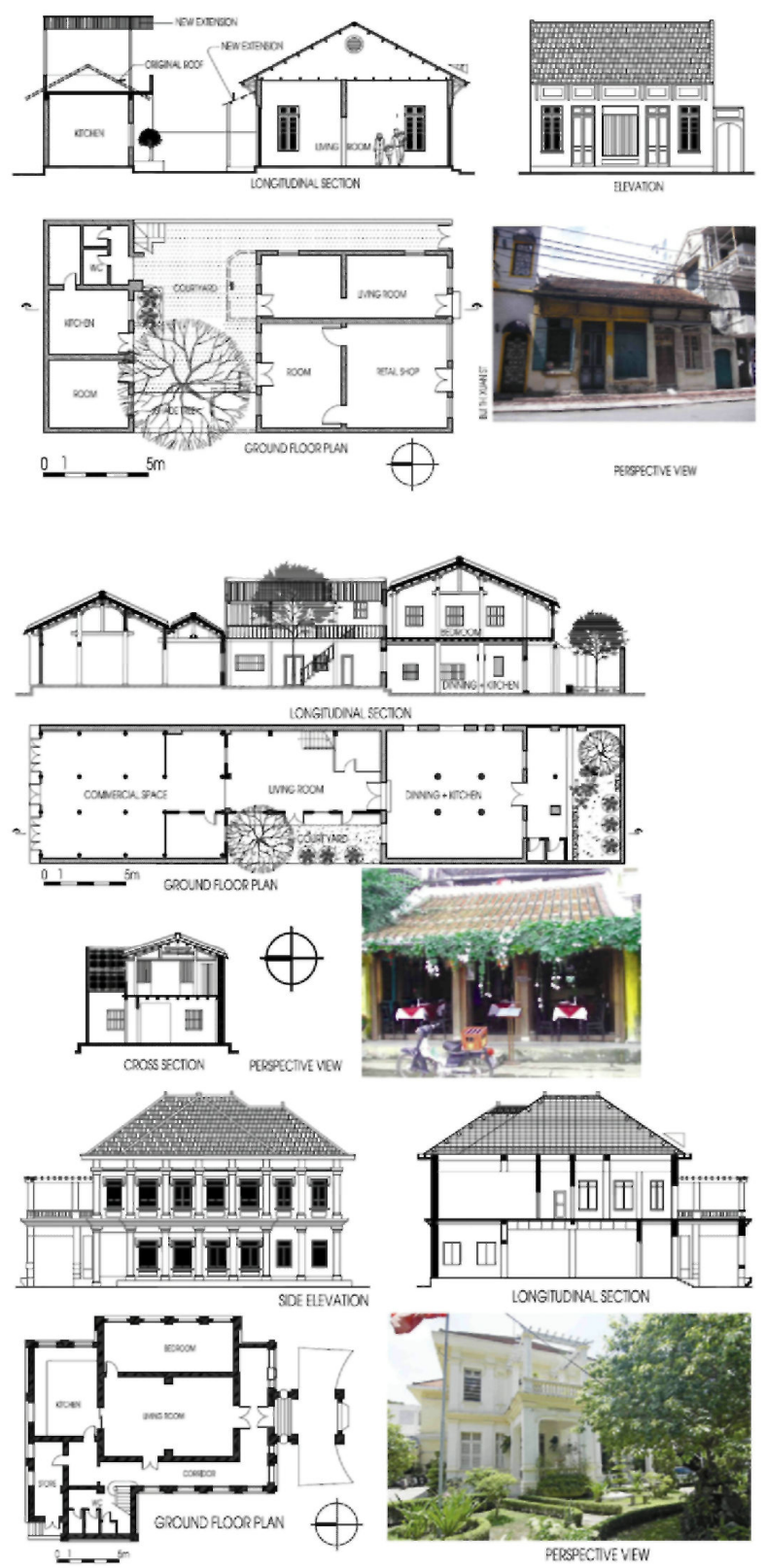
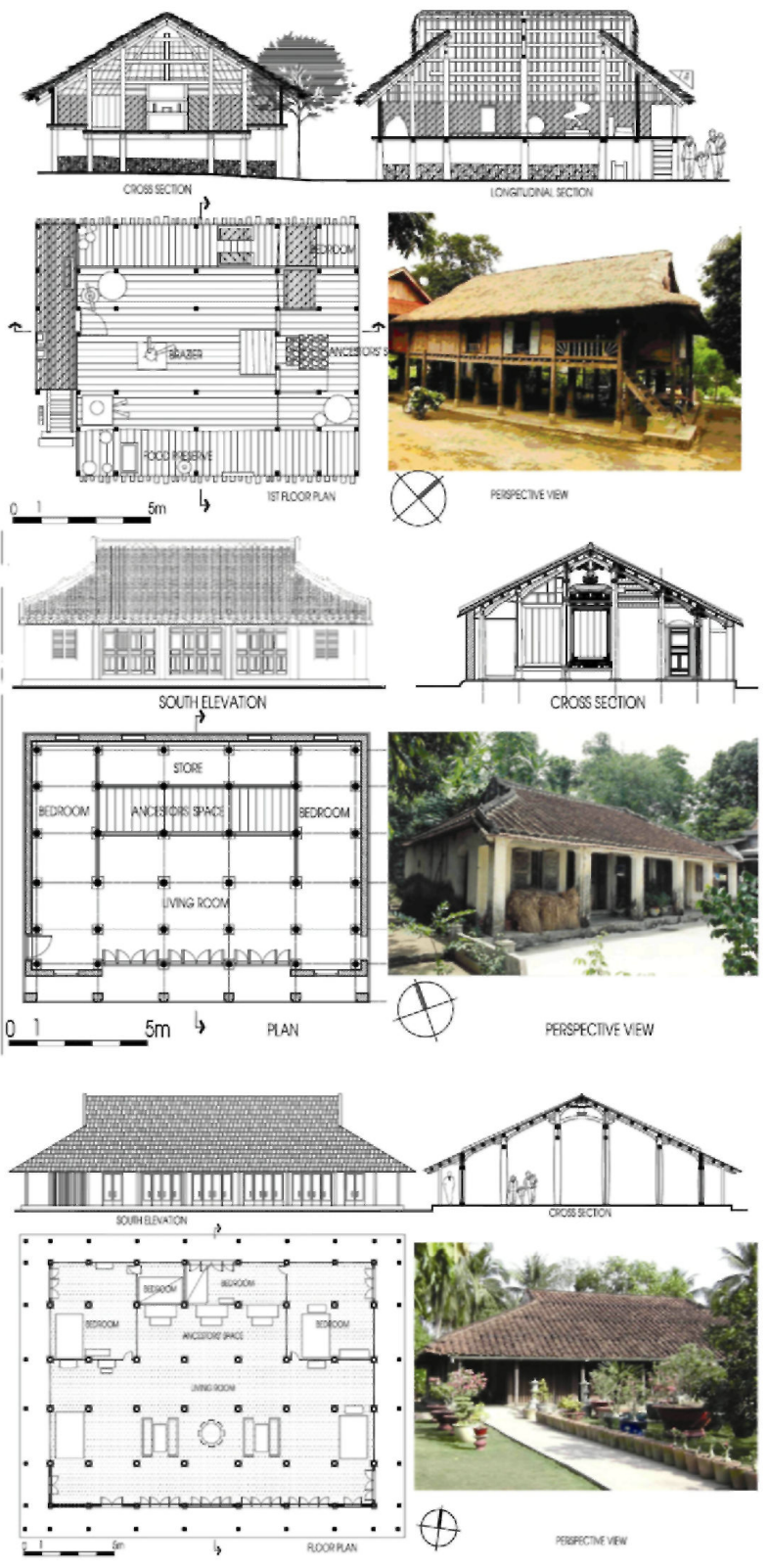


\section{Theory, measurement, calculation and results}

\subsection{Step 1: climate zoning and selected sites of the survey}

All the climatic data used in this analysis were gathered from Vietnam Building Code 2009 [8]. Data in the Code is based on monitoring data over several years from Meteorological stations of the Vietnam General department of Hydrometeorology. In this analysis, three typical sites, including Hanoi (latitude: $21^{\circ} \mathrm{N}$ ), Danang (latitude: $16^{\circ} \mathrm{N}$ ) and Hochiminh city (latitude: $11^{\circ} \mathrm{N}$ ), which represent the three climatic regions in the North, Centre and South of Vietnam, were selected (see Fig. 2). Weather conditions in December and June, representing the winter and summer periods, were chosen for analysis and comparison.

Fig. 3 shows all climatic data of three selected sites in the diagrams and charts. It is clear that the Sun mainly moves on the South sky of the observation points; and the three sites have very high solar radiation, relative humidity and average yearly rainfall. We also emphasise the following points on the climatic features of each site:

- Hanoi has a short cold winter, but the lowest temperature hardly falls below $5{ }^{\circ} \mathrm{C}$. The highest temperature can reach $40{ }^{\circ} \mathrm{C}$. Temperature and humidity are generally moderate. Rainfall as well as rain intensity are more significant. Protection from the cold winds is required in winter. Generally, Hanoi is not affected by tropical storms.

- In Danang, the climate is tropical with monsoons. The winter is not cold and the lowest temperatures are often well above $10^{\circ} \mathrm{C}$. The highest temperatures can exceed $40^{\circ} \mathrm{C}$. Because of the impact of the sea, daily and yearly temperature ranges are quite small. Protection from the cold is not required. Coastal parts are directly influenced by strong tropical storms and rainfall often peaks during the month of October making appropriate roofing essential.

- Hochiminh city has a hot and humid climate with monsoons all year round. There are only two annual contrasting seasons; dry and wet, both consistent with two inhomogeneous monsoons in the region. Rainfall is quite high. Air temperature and solar radiation are quite high all year which indicate that cooling is in demand. Wind is abundant all year round and this resource can be exploited for passive cooling strategies, especially when the hot weather is uncomfortable.

\subsection{Step 2: collecting data}

Vietnam is a country of rivers. Its origins can be traced from two big deltas established by the Hong river in the North and the Cuu Long river in the South. In ancient times, Viet people travelled on boats, and then lived in stilt houses which have influenced current communal houses (see Fig. 4). Today, in many parts of Vietnam, people still live in stilt houses like their ancestors did.

Most traditional houses in Vietnam have been destroyed or have completely disappeared due to damage caused by wars, natural disasters and even the policies of both feudalism and the government. Those remaining, among which the most ancient house (property of the Nguyen Thac family) was built in 1734 [9], are modest in size and age.

This study investigated six typical houses in three climatic regions mentioned in Section 3.1. Each region is represented by two houses: one in an urban area and the other in a rural area, since many significant differences between these two housing styles exist. Urban houses are typically large, multi-functional, and influenced by foreign architectural styles whereas rural houses are smaller, purely vernacular and are only used for living purposes. All six houses are typical in terms of style and size and are in good state of repair. The purpose of this selection is to find the climate responsive designs corresponding to all climate types in Vietnam. Architectural details of these selected houses are presented in Fig. 5 and their specific data is listed in Table 1.

It is well-known that vernacular housing all over the world makes use of materials found locally which reduces energy consumption and environmental impact and also encourages local characteristics which is also the case of the houses studied (see Table 2).

Among the above mentioned materials, some types were widely used in housing construction in Vietnam, especially in rural areas, until the end of the 20th century. These materials have certain advantages and positive characteristics as described in Table 3. 
Table 1 General information about the houses in question.

\begin{tabular}{|c|c|c|c|c|c|c|}
\hline Code & Location & $\begin{array}{l}\text { Climatic } \\
\text { region }\end{array}$ & $\begin{array}{l}\text { Year of } \\
\text { cons. }\end{array}$ & Architectural style & Function & Construction method \\
\hline House A & $\begin{array}{l}102 \text { Bui Thi Xuan st, Hanoi } \\
\text { city }\end{array}$ & North & 1920 & $\begin{array}{l}\text { Traditional urban } \\
\text { style }\end{array}$ & $\begin{array}{l}\text { Commercial } \\
\text { and living } \\
\text { space }\end{array}$ & $\begin{array}{l}\text { Traditional methods - } \\
\text { workers were employed } \\
\text { from adjacent trade villages } \\
\text { of Hanoi }\end{array}$ \\
\hline House B & Hoabinh province & North & $\mathrm{NA}^{\mathrm{b}}$ & Vernacular style & Living space & $\begin{array}{l}\text { Mainly by owners with } \\
\text { unwritten experience from } \\
\text { their ancestors. }\end{array}$ \\
\hline House C & 75 Tran Phu, Hoian city & Central & 1860 & $\begin{array}{l}\text { Traditional - } \\
\text { Japanese } \\
\text { influence }\end{array}$ & $\begin{array}{l}\text { Commercial } \\
\text { and living } \\
\text { space }\end{array}$ & $\begin{array}{l}\text { By local skilled workers of } \\
\text { traditional carpenter bands, } \\
\text { e.g. Kimbong or Vanha }\end{array}$ \\
\hline House D & $\begin{array}{l}\text { Tien Canh ward, Tienphuoc } \\
\text { district, Quangnam province }\end{array}$ & Central & 1890 & Vernacular style & Living space & $\begin{array}{l}\text { Traditional methods - by } \\
\text { local skilled workers of } \\
\text { traditional carpenter bands }\end{array}$ \\
\hline House E & $\begin{array}{l}32 \text { Tran Quoc Thao st, } \\
\text { Hochiminh city }\end{array}$ & South & $1920^{\mathrm{a}}$ & Colonial style & Living space & $\begin{array}{l}\text { By French design and local } \\
\text { builders }\end{array}$ \\
\hline House F & $\begin{array}{l}\text { Tan LyTay ward, Chauthanh } \\
\text { district, Tiengiang province }\end{array}$ & South & $\begin{array}{l}1901- \\
1904\end{array}$ & Traditional style & Living space & $\begin{array}{l}\text { By local skilled workers of } \\
\text { traditional carpenter bands } \\
\text { from Central Vietnam }\end{array}$ \\
\hline
\end{tabular}

Table 2 Types of materials used in the houses investigated.

\begin{tabular}{|c|c|c|c|c|c|c|}
\hline Code & Foundation & Wall & Structure & Roof & Floor & Openings \\
\hline House A & $\begin{array}{l}\text { Normal solid } \\
\text { fired clay } \\
\text { brick }\end{array}$ & $\begin{array}{l}\text { Solid brick wall with } \\
\text { plaster on both sides }\end{array}$ & $\begin{array}{l}\text { Load bearing } \\
\text { wall and } \\
\text { timber }\end{array}$ & $\begin{array}{l}\text { Fired clay tile on timber } \\
\text { frame }\end{array}$ & Cement tiled floor & $\begin{array}{l}\text { Timber and } \\
\text { glass }\end{array}$ \\
\hline House B & $\begin{array}{l}\text { No } \\
\text { foundation }\end{array}$ & $\begin{array}{l}\text { Bamboo lattice or } \\
\text { wooden panel }\end{array}$ & $\begin{array}{l}\text { Bamboo and } \\
\text { wooden frame }\end{array}$ & $\begin{array}{l}\text { Thatch (rice straw, thatch, } \\
\text { reeds, palm leaves...) }\end{array}$ & $\begin{array}{l}\text { Broken } \\
\text { neohouzeaua }^{c}\end{array}$ & Bamboo lattice \\
\hline House C & $\begin{array}{l}\text { Stone or } \\
\text { burned clay } \\
\text { brick }\end{array}$ & $\begin{array}{l}\text { Fired - clay bricks } \\
\text { with plaster on both } \\
\text { sides }\end{array}$ & Hard timber & $\begin{array}{l}\text { Fired clay tile on timber } \\
\text { frame }\end{array}$ & $\begin{array}{l}\text { Fired clay brick - } \\
\text { wooden floor }\end{array}$ & Wooden panel \\
\hline House D & $\begin{array}{l}\text { Laterite } \\
\text { stone }^{\mathrm{a}}\end{array}$ & $\begin{array}{l}\text { Mixture of clay and } \\
\text { straw on bamboo } \\
\text { lattice }^{\text {b }}\end{array}$ & Hard Timber & $\begin{array}{l}\text { Two layers: Thatch roof } \\
\text { (upper) and ramped earth } \\
\text { (lower) }^{\mathrm{d}}\end{array}$ & Ramped earth & Wooden panel \\
\hline House E & Stone & $\begin{array}{l}\text { Fired - clay brick } \\
\text { with plaster on both } \\
\text { sides }\end{array}$ & $\begin{array}{l}\text { Load bearing } \\
\text { wall }\end{array}$ & $\begin{array}{l}\text { Fired clay tile on timber } \\
\text { frame }\end{array}$ & $\begin{array}{l}\text { Reinforced } \\
\text { concrete }+ \text { cement } \\
\text { tiles }\end{array}$ & Wooden panel \\
\hline House F & $\begin{array}{l}\text { No } \\
\text { foundation }\end{array}$ & $\begin{array}{l}\text { Wooden panel - } \\
\text { vertical bars }\end{array}$ & Hard timber & $\begin{array}{l}\text { Fired clay tile on timber } \\
\text { frame }\end{array}$ & Fired clay brick & Wooden panel \\
\hline
\end{tabular}


Table 3 Most used materials and their properties.

\begin{tabular}{|c|c|c|}
\hline Materials' name & Advantages $^{\mathrm{a}}$ & Notes \\
\hline Bamboo & $\begin{array}{l}\text { High durability }{ }^{\mathrm{b}} \text {, local availability, easy fabrication, multi- } \\
\text { purpose usage, high tensile strength (up to } 200 \mathrm{MPa} \text { ), } \\
\text { compressive strength up to } 70 \mathrm{MPa} \text {, light - weight material (about } \\
630 \mathrm{~kg} / \mathrm{m}^{3} \text { ) }\end{array}$ & Fire prevention \\
\hline Laterite stone & $\begin{array}{l}\text { Very high durability, local availability, high moisture absorption, } \\
\text { suitable for walls (compressive strength } 20-30 \mathrm{MPa})^{\mathrm{c}}\end{array}$ & Only available in some regions \\
\hline Ramped earth & $\begin{array}{l}\text { Available in most regions, multi-purpose usage, easy fabrication, } \\
\text { low compressive strength }(0.84-0.92 \mathrm{MPa})\end{array}$ & Humidity control \\
\hline Clay-straw mixture & $\begin{array}{l}\text { Available in most regions, easy fabrication, low thermal } \\
\text { conductivity }(0.18 \mathrm{~W} / \mathrm{m} \mathrm{K})\end{array}$ & $\begin{array}{l}\text { Low compressive strength }(<4.6 \\
\mathrm{MPa}) \text {, erosion by rain }\end{array}$ \\
\hline Thatch & $\begin{array}{l}\text { Extremely low thermal conductivity }(0.07 \mathrm{~W} / \mathrm{m} \mathrm{K}) \text {, local } \\
\text { availability, light - weight material }\left(240 \mathrm{~kg} / \mathrm{m}^{3}\right) \text {, easy fabrication }\end{array}$ & $\begin{array}{l}\text { Insect and fire prevention (about } \\
180 \mathrm{~J} / \mathrm{kg} \mathrm{K} \text { ), durability }\end{array}$ \\
\hline
\end{tabular}

\subsection{Step 3: invesngation of housing climate responsive design strategies}

Popular climatic strategies used in the built environment in hot humid regions were categorised and numbered as 17 architectural solutions as follows:

1. Building orientation and shape

2. Solar shading

3. Natural ventilation (cross ventilation (a), stack ventilation (b), single-side ventilation (c))

4. Natural lighting techniques

5. Light weight construction

6. High thermal mass

7. Evaporative cooling

8. Earth cooling

9. Passive cooling by using colour

10. Thermal insulation by material

11. Thermal insulation by design (e.g. well ventilated attic, double-skin facade...)

12. Passive solar energy

13. Storm prevention

14. Flood prevention

15. Rainwater discharge

16. Moisture and condensation prevention

17. Others

These 17 strategies applied in these selected houses were qualitatively investigated and evaluated using the "Descripnon and Image" approach. In this approach, the criteria of assessment is that if there is at least one climate responsive solution which corresponds to each of the local climatic features, the house is considered completely adapted to its local climate. Conversely, if no adaptation measures are found, the house is regarded as completely unadapted. In practice, most of the houses are neither completely adapted nor completely unadapted and are usually within this range. Subsequently, the following points were carefully examined: the advantages and disadvantages of local climatic features were identified; the drawings and photos of the buildings were analysed to show climate responsive solutions and their effectiveness; qualitative assessments were then derived based on the criteria and analysis illustrated in Table 4-6.

Detailed analysis in Table 4-6 reveals that vernacular housing in different regions of Vietnam has adapted relatively well to the climate as well as adverse weather conditions. Though the solutions employed are considered simple, inexpensive and easy to apply, they proved to be very effective, demonstrating a deep understanding of the ancestors about the building and its surrounding environment.

Other findings were also obtained. All strategies used were numbered and their usages were listed in Table 4-6. Consequently, the frequency of use of each strategy in these houses was found and illustrated in Fig. 6. This 
graph shows that in all regions natural ventilation was the most used strategy whereas earth cooling and passive solar energy were not employed. Sophisticated technical requirements may be the main reason that passive solar energy was not employed for heating in vernacular housing, but solar heating has a potential to be applied in Vietnam and needs to be investigated further. Other findings are that it is suitable and effective to employ natural ventilation, building orientation - building shape and solar shading strategies in Vietnamese climatic conditions while earth cooling, thermal insulation and high thermal mass are inappropriate. Storm prevention was only found in central Vietnam where tropical storms usually hit. Due to time and resource limitations, this preliminary investigation included only six buildings. The findings can be consolidated by larger investigations.

\subsection{Step 4: full-scale measurement of micro-climate in a house}

In order to have a more accurate assessment than the qualitative one mentioned above, an in-situ survey and measurement was carried out in Hanoi. Since investigations on all six houses would not be feasible, this study targeted the house at $\mathrm{N}^{\circ} 102$ Bui Thi Xuan street in Hanoi as the unique building of full-scale measurement. The survey was continuously conducted from $8 \mathrm{~h}$ to $21 \mathrm{~h}$ on a typical summer day and winter day in Hanoi (16 December and 22 August).

All measurements were in relation to four physical climatic indexes: air temperature, relative humidity, wind velocity and natural illuminance. The results shown here are the averaged values of 10-min measurements (for mean wind velocity) and of 3-min measurements (forothervariables). The measuring points were distributed as shown in Fig. 7. The indoor air temperature, humidity, wind velocity and natural illuminance were measured at head level of a sitting person (height of $1.1 \mathrm{~m}$ ) as recommended by ISO 7726 [15]. During measurement periods, openings of the house were operated by the occupants, adapting to outdoor conditions. Measuring instruments are listed in Table 7. The results for illumination were compared with requirements in the Vietnam building code [16] as shown in Table 8.

Table 4 Qualitative investigation of bioclimatic design strategies used in traditional architecture - North of Vietnam.

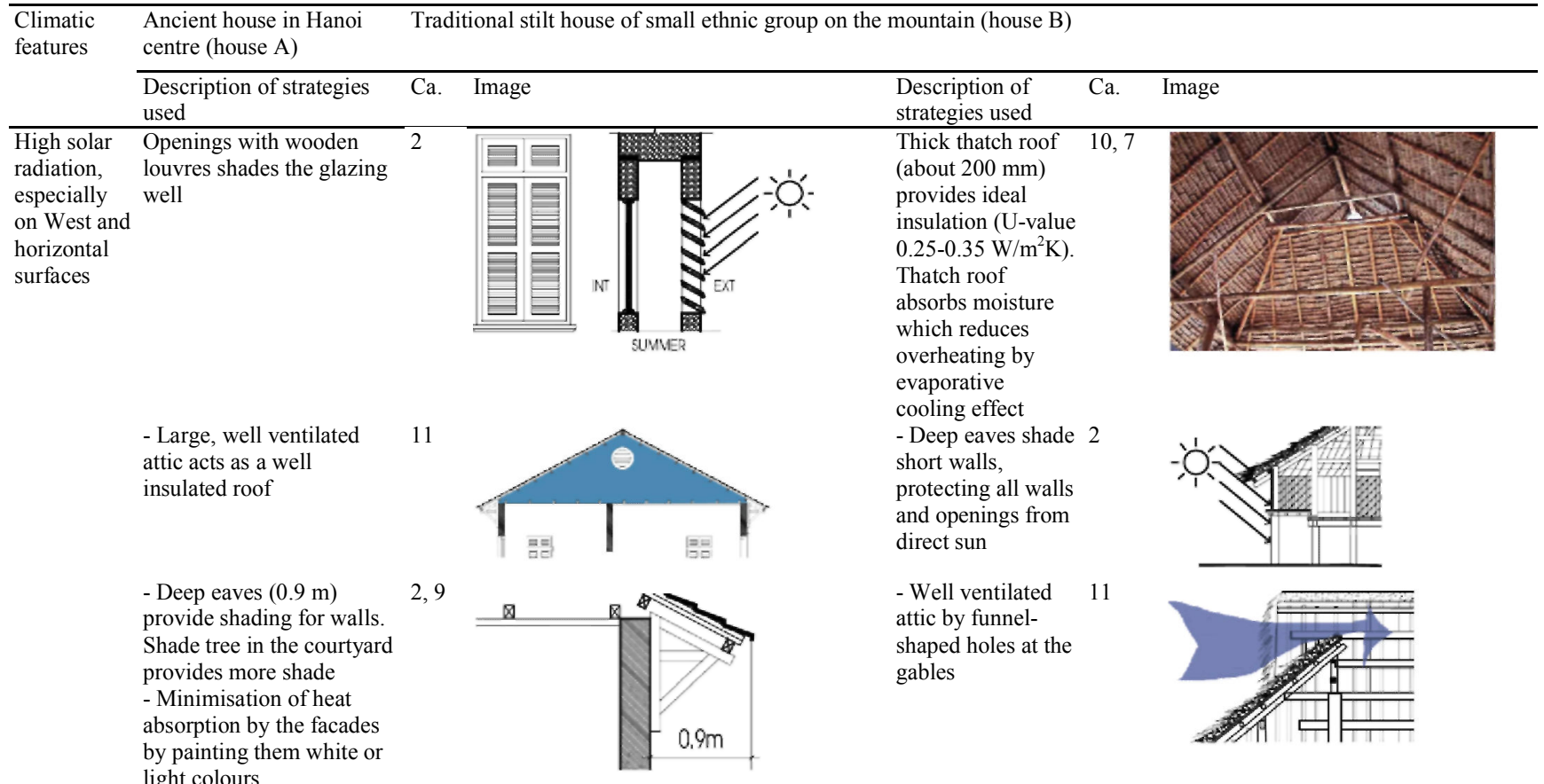




$\begin{array}{ll}\text { High } & \text { - Room height is } 3.9 \mathrm{~m}-4.2 \quad 3 \mathrm{a} \\ \text { average } & \mathrm{m} \text { and many large } \\ \text { temperature } & \text { openings improve } \\ \text { and } & \text { ventilation } \\ \text { humidity } & \end{array}$

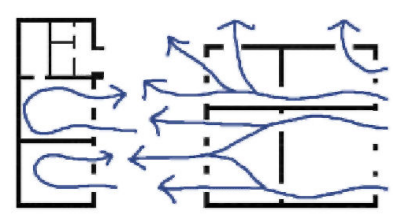

- Large and long courtyard $3 \mathrm{a}$ helps e nhance natural ventilation and reduces humidity. Side corridor induces wind into the courtyard.
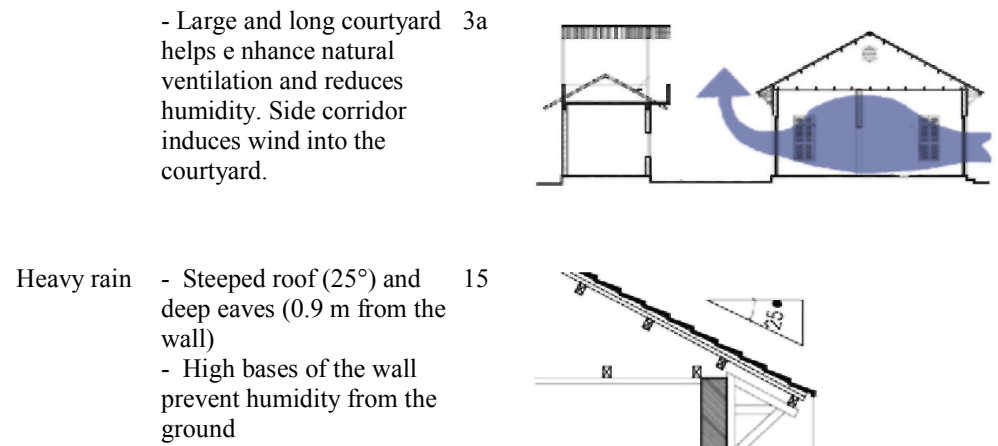
prevent humidity from the ground

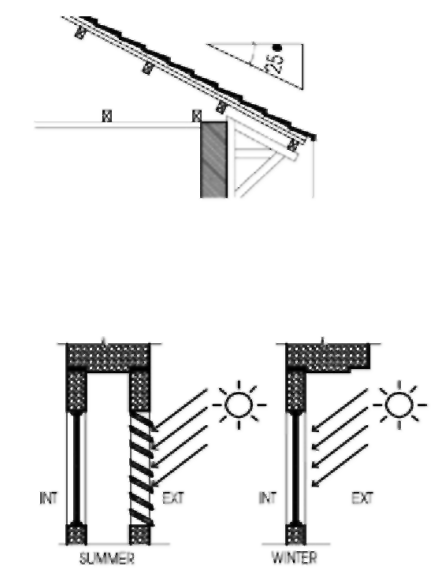

North cold Building orientation strategy for prevailing wind is NOT available due to its wind,

South-East

cool wind

Sun path on Strategies NOT clear due the South to its location in city centre sky

- Two layered window different (French window) provides seasons (hot flexible and operable and fairly control of openings during cold) hot and cold periods

Stilt house easily meets airflow at higher speed. Wind speed at height $2 \mathrm{~m}$ can be 2 times as high as that at $1 \mathrm{~m}$.

The air near the ground is often stagnant

The house is raised 16 $1.6 \mathrm{~m}$ above ground to prevent moisture entering from the ground

\section{- Steeped roof $\left(32^{\circ}\right)$ and deep eaves ( $1 \mathrm{~m}$ from the wall) enhance rainwater discharge}

Not highly influential because of the deep eaves around the house

- Cooking (brazier) 17, 3b is done right at the middle of the house to keep warm in winter. - Openings on the gables enhance stack effect and release smoke from the brazier

Windows are oriented to the

South; cross

ventilation through

door, windows, and openings on the gables. When there is no wind, stack effect increases airflow Light weight building

components: thatch roof, bamboo lattice enclosure with high porosity, bamboo floor and wooden column

House on stilts adapts well to floods (from high mountain) and prevents wild animals (snakes, centipedes, insects etc.) from entering

15

$1,3 \mathrm{a}$

14
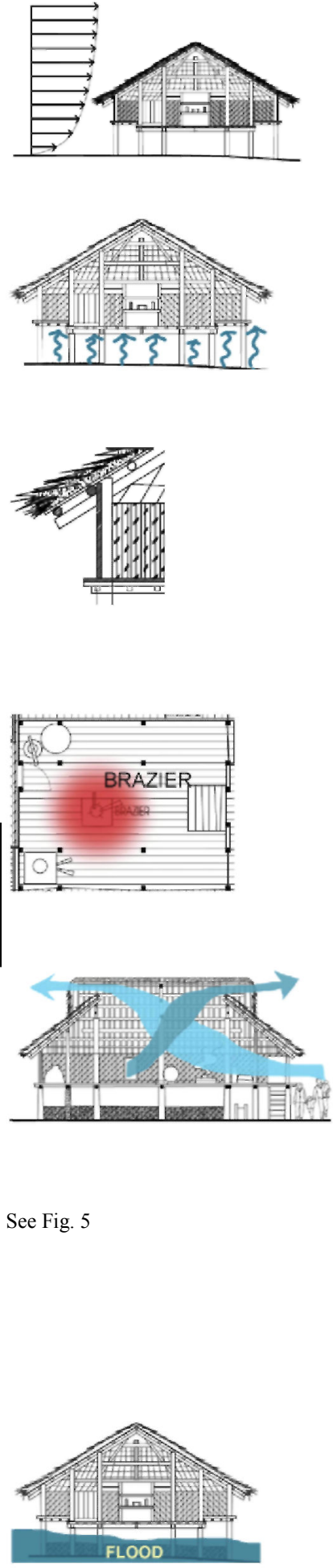
and light from the courtyard

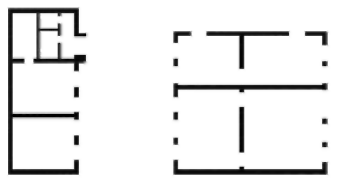


Table 5 Qualitative investigation of bioclimatic design strategies used in traditional architecture - Centre of Vietnam.

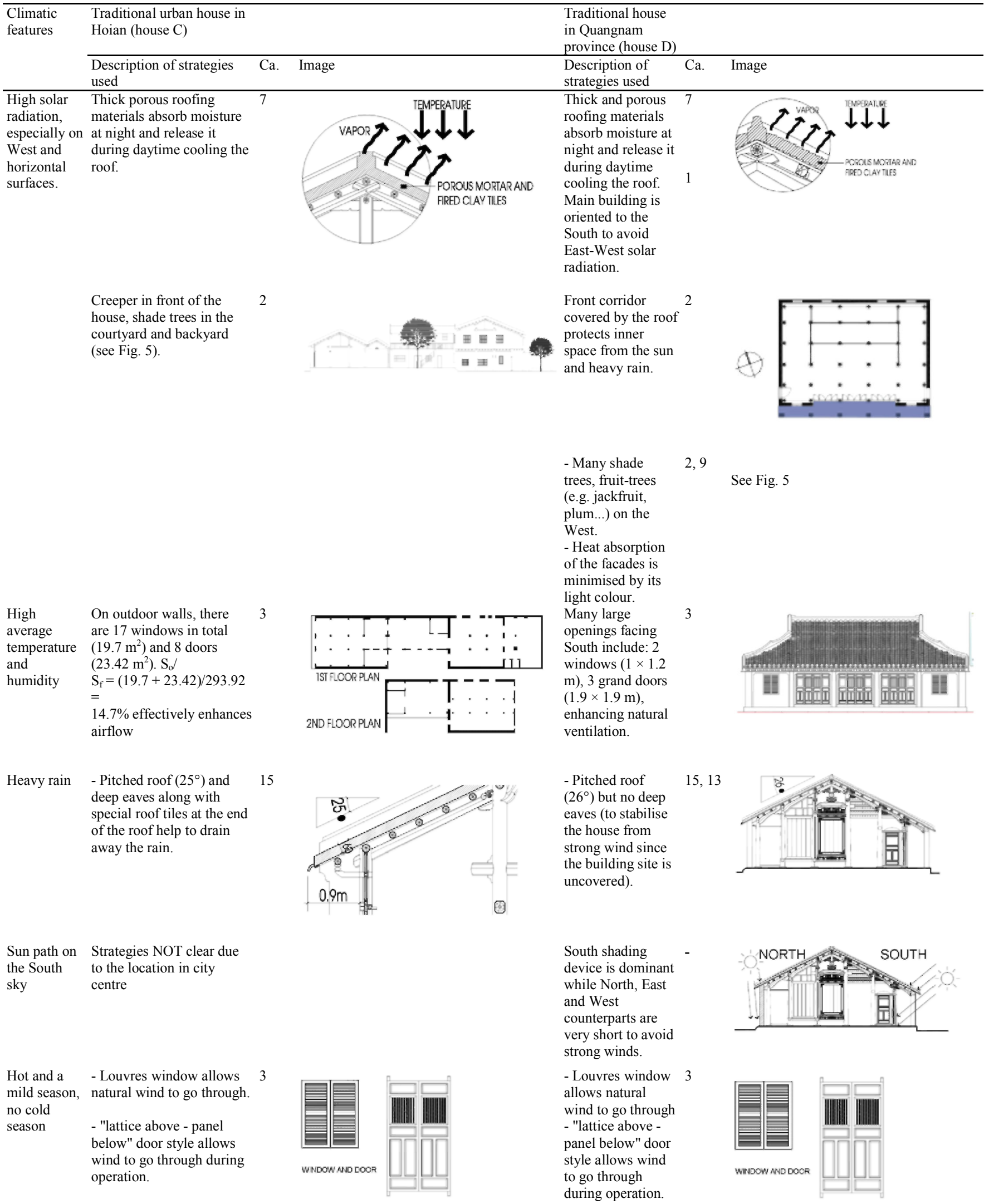


East and

South-East cool wind

- Building orientation strategy is NOT available due to its location in city centre.

- Front street, large courtyard and backyard improve cross ventilation. - Lighting condition is improved by the courtyard.

Small diurnal and seasonal temperature - humidity

range

Flood - up

Due to its location very

to $2.5 \mathrm{~m}$ (in close to the river mouth by 1966) the sea, building a twostorey house helps to minimise inconvenience caused by annual floods as the second floor level was always higher than the peak flood.

Others

The front part served as commercial space, facing the crowded street while the living space was separate towards the back and isolated from the front part by a large courtyard
3,4

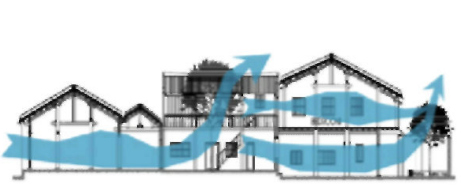

- The house is oriented to the South to catch the

prevailing wind.

Building blocks were separately

distributed

- Banana trees

behind the house

block cold wind.

Front yard

enhances wind

induced ventilation

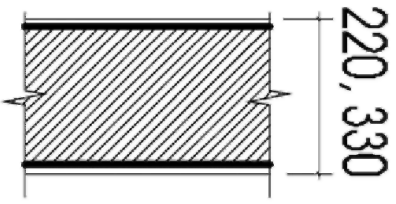

- Light weight construction (thin

load bearing wall $220 \mathrm{~mm}$ )

- Insulation was not used

13

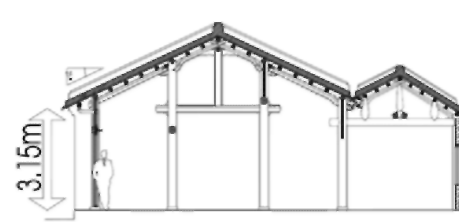

- Low, thick and heavy roof (only $2.2 \mathrm{~m}$ from the ground), short

eaves on other sides of the house

- Strong wind (from the East) can only attack side walls of the house

Not flooded because of it location on a midland

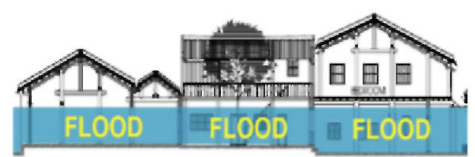

region

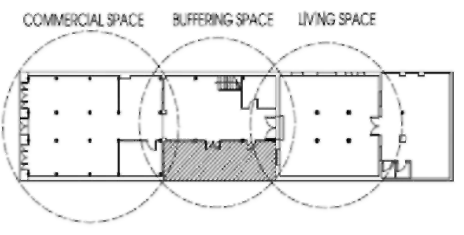

Except the front yard, shade trees have been planted around the house, providing effective shading and cooling down the air temperature
13,1

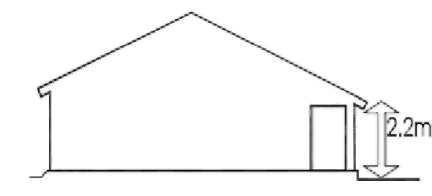

1,3
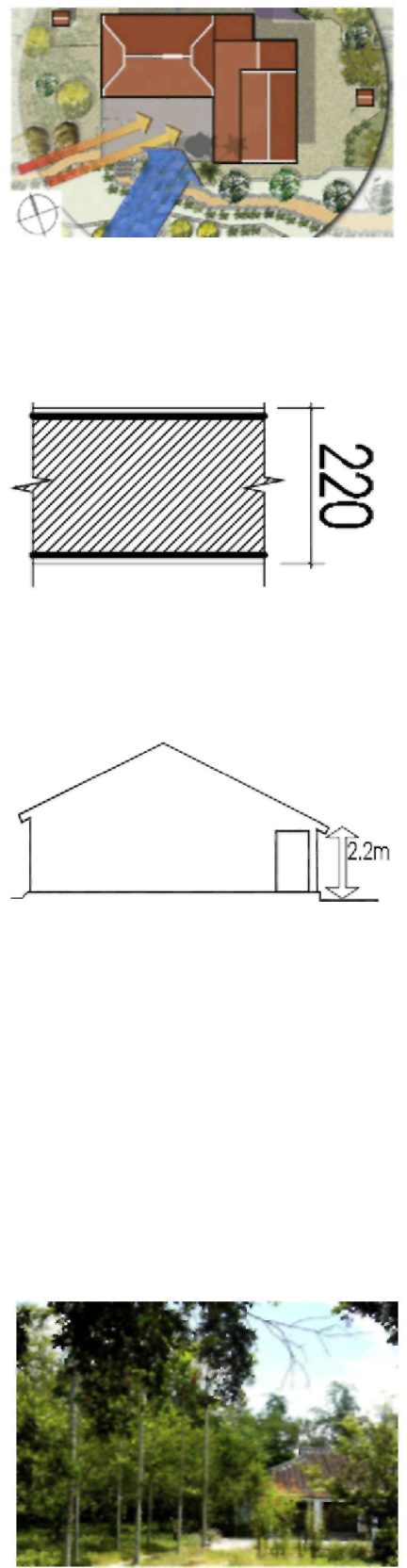
Table 6 Qualitative investigation of bioclimatic design strategies used in traditional architecture - South of Vietnam.

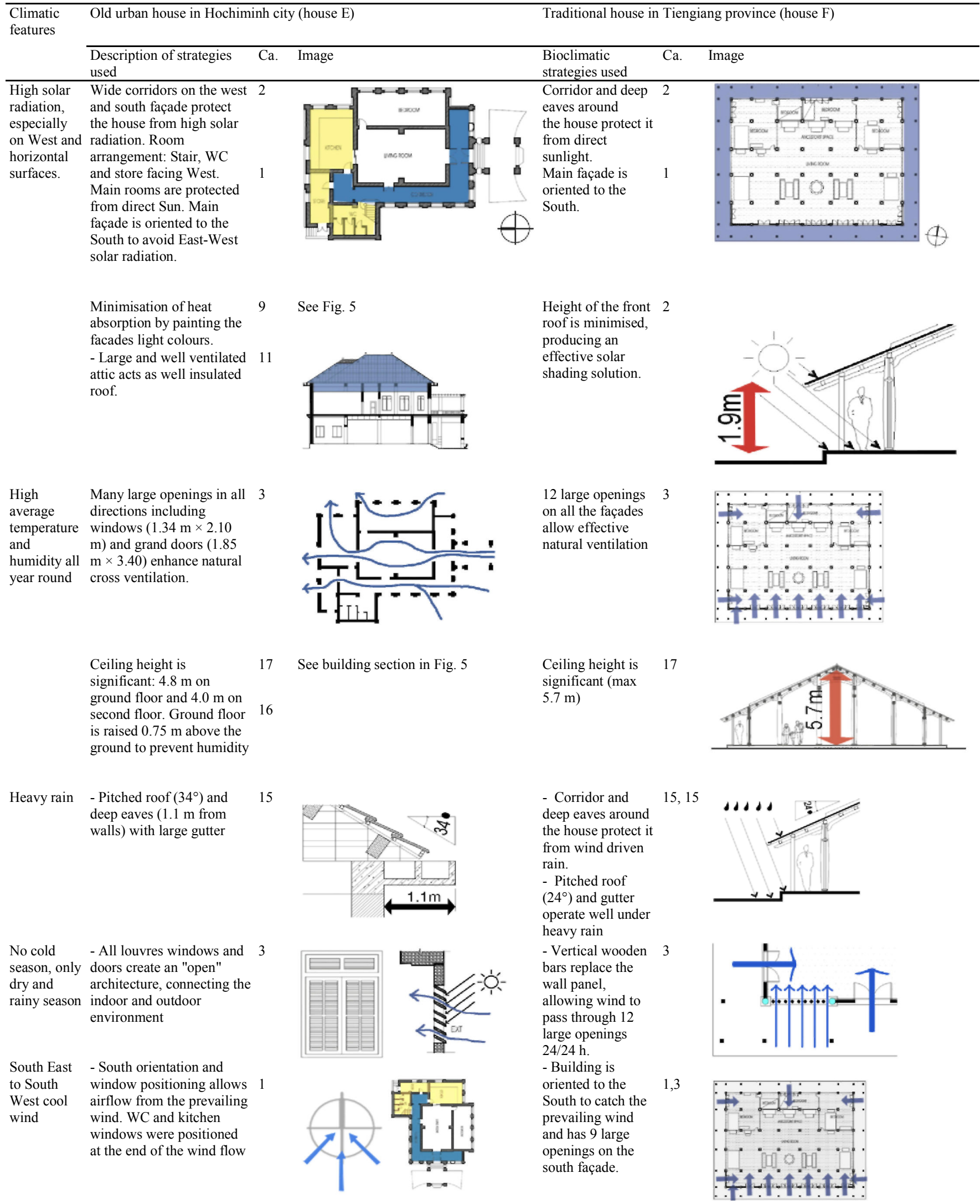




\begin{abstract}
Small
diurnal and

seasonal

temperature

- humidity

range

- Thick load bearing wall

(400 $\mathrm{mm}$ on average),

combined with many large

openings and transitional

space (corridor), provide

flexible control of the

indoor environment.
\end{abstract}

Others

The many openings provide enough natural light for occupied rooms

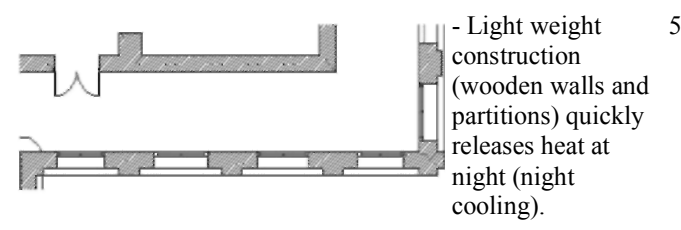

More openings on 4 the south façade obtain more natural light as the sun mainly moves in the south sky

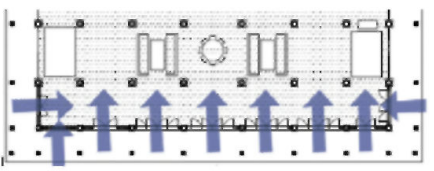

Fig. 6. Frequency of use of different climatic responsive strategies.

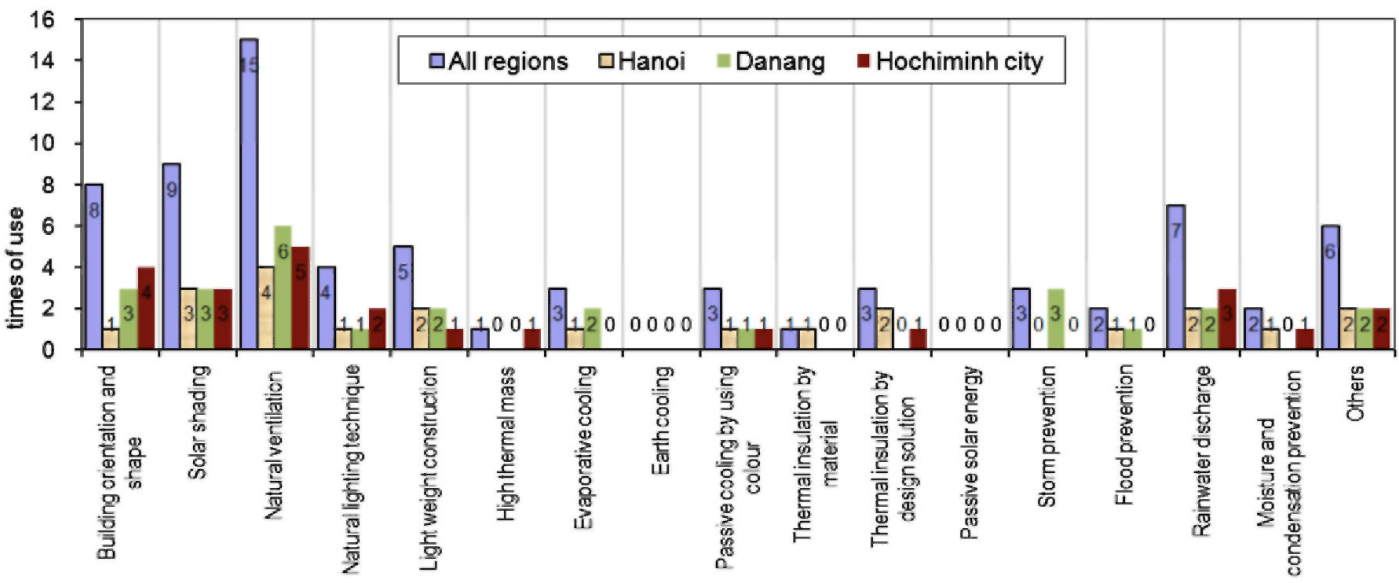

Fig. 7. Distribution of measuring points $(1,2, \ldots, 10$ are illumination measuring points; $A, B, \ldots, E$ correspond with measuring points of other variables).

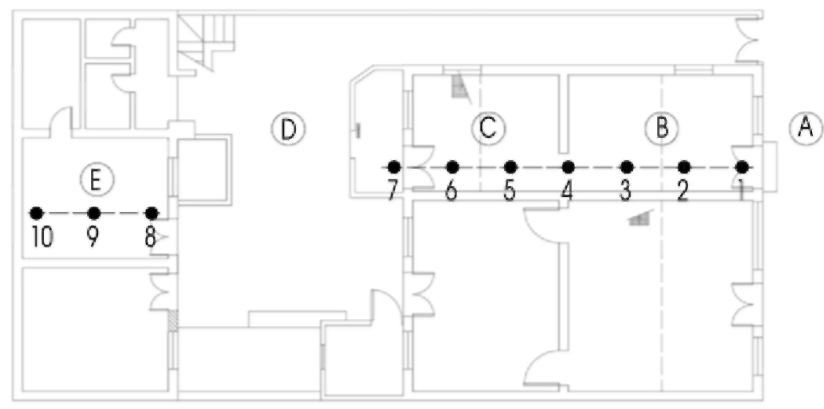

Table 7 Measurement instruments and their properties.

\begin{tabular}{llccc}
\hline Environmental indicator Instrument & Quantity & Accuracy & Response time \\
\hline Temperature & Asman & 3 & $\pm 0,2{ }^{\circ} \mathrm{C}$ & $60 \mathrm{~s}$ \\
Illumination & Testo & 3 & $\pm 1 \%$ & $1 \mathrm{~s}$ \\
Wind velocity & Kata & 2 & $\pm 2 \%$ & Depended on the wind \\
Humidity & Asman & 3 & $\pm 3 \%$ & $60 \mathrm{~s}$ \\
\hline
\end{tabular}


Table 8 Vietnam building code of natural illumination for residential facilities.

\begin{tabular}{lcc}
\hline Index & Main room & Toilet and store \\
\hline Illumination coefficient & $0.5 \%$ & $0.3 \%$ \\
Minimum illumination & $50 \mathrm{lux}$ & $30 \mathrm{lux}$ \\
\hline
\end{tabular}

\subsubsection{Results recorded}

Average air temperature, humidity and wind velocity at survey points were plotted on a combined diagram shown in Fig. 8. As can be seen from Fig. 8, there are no significant disparities between indoor and outdoor temperature as well as humidity except humidity at point $\mathrm{E}$ (in the kitchen) which was a little higher because of its earthen floor. This demonstrates that good ventilation of indoor space was achieved. However, daytime ventilation in summer was not appropriate since outdoor temperature was rather high. This corresponds to the study carried out by Kubota et al. [17] in which they reported that in a hot humid climate, night ventilation effectively reduces indoor operative temperature and improves thermal comfort, but the majority of occupants tend to apply not night ventilation but daytime ventilation mainly due to insects, security risks and rain. Fig. 8 also reveals that indoor wind velocity achieved in the survey was not sufficient to remove heat and humidity in summer, but was a little high in winter. High indoor wind velocity in winter could be easily reduced by an appropriate openings control. Natural ventilation performance and humidity at point $\mathrm{E}$ was worst since this room uses single-side ventilation.

Indoor and outdoor hourly temperature, humidity and wind velocity were also compared as shown in Fig. 9. It is clear that indoor parameters were similar to those measured outdoors. The fluctuation of indoor humidity might be caused by occupants' activities (cooking, washing et cetera). These confirm the "open" characteristics of this house which are generally recommended for hot humid climates. Another finding is that the wind velocity at point D (in the courtyard) was independent of wind conditions at point A (in front of the house). This improves natural ventilation of the rooms facing the courtyard.

In order to evaluate indoor thermal comfort, $\mathrm{PMV}$ index at point $\mathrm{C}$ in the summer and winter day was calculated using measured results. In this study, PMV calculation is based on PMV - calculator of professor de Dear [18] and on the following assumptions: average occupant's height: $1.65 \mathrm{~m}$, weight: $60 \mathrm{~kg}\left(A_{\text {dubois }}=1.65 \mathrm{~m}^{2}\right)$, wearing clothes at 0.5 clo in summer and 1.0 clo in winter at sedentary work $\left(70 \mathrm{~W} / \mathrm{m}^{2}\right)$, exposure time of $60 \mathrm{~min}$, mean radiant temperature is also assumed to be equal to air temperature.

Although PMV-PPD model is the basis of comfort standards ISO 7730 [19] and ASHRAE 55 [20], it was assumed to be inaccurate in predicting thermal sensation of the occupants in a naturally ventilated building in hot humid climate since it neglects human physiological, behavioural and psychological adaptations [21 ]. Thus, PMV results from the summer day are corrected by an expectancy factor $e=0.6$ (for Hanoi - assumed to be equal to Bangkok) [22].

As shown in Fig. 10, PMV of a winter day was completely in the comfort range and could be improved by an appropriate control of openings. However, PMV of the summer day was well between slightly warm and warm scale. This PMV analysis reveals that the house performs fairly well in winter, but it needs other strategies to maintain human comfort in summer. Two possibilities are proposed: (1) combining better thermal insulation for the enclosure with night ventilation or (2) employing mechanical support during extreme conditions.

Natural illuminance of the 10 survey points on the winter day (16 December, $15 \mathrm{~h}$ ) is illustrated in Fig. 11. During the measurement period, the sky was completely obstructed by the cloud cover and outdoor illuminance was around 5000 lux. Although the house has many openings, it is a little surprising that some indoor points did not have enough light according to the current Building code of Vietnam while others exceeded. This suggests that many openings should be appropriately distributed to achieve better lighting. 
Fig. 8. Average air temperature, relative humidity and scalar wind velocity at surveyed points in a typical summer and winter day (measurement at point E in summer was unavailable due to construction work being done there).

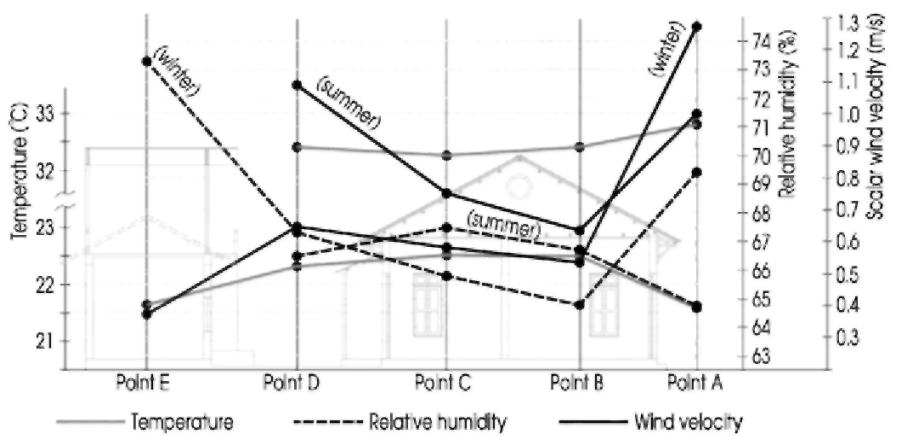

Fig. 9. Change of temperature, humidity and wind velocity at some survey points during a typical summer and winter day.
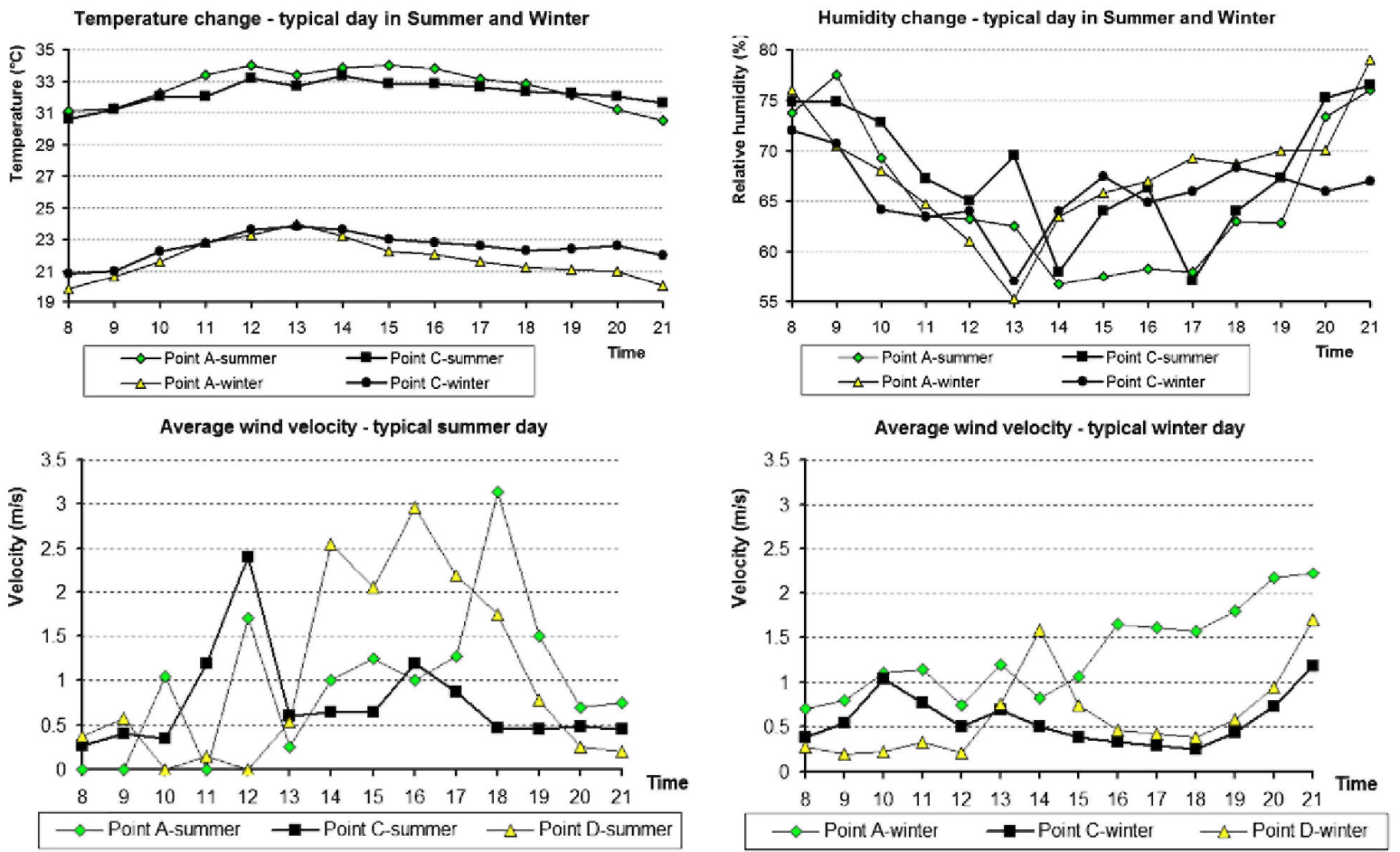
Fig. 10. Indoor thermal comfort evaluation through PMV model.

PMV index variation - typical day in Summer and Winter

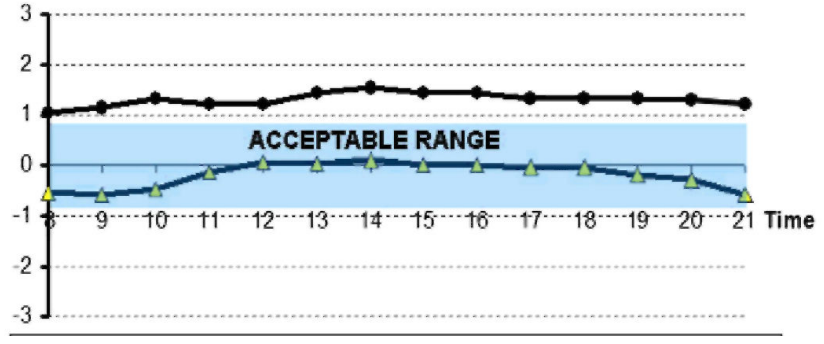

\subsection{Step 5: whole - year simulation of building performance}

In recent years, building simulation has become an effective method to predict building performance and save time and resources. It also gives predictions for numerous different cases and can simulate extremely complicated circumstances which people rarely examine by experimental methods. Nevertheless, it is recommended that the reliability of simulation results be carefully validated before use. The present study employs three simulation tools, including CFD tool, solar tool and thermal prediction tool which will be presented in the following sections.

\subsubsection{Study on natural ventilation performance of the house}

Natural ventilation of various situations of house A was examined using Computational fluid dynamics (CFD) method. RNG k- $\varepsilon$ turbulence model in conjunction with Phoenics code was used as it was reported to be one of the most reliable two-equation turbulence models for indoor and outdoor airflow applications [23,24]. RNG k- $\varepsilon$ turbulence model was also proved to be effective in predicting cross ventilation by the authors [25]. Although CFD simulation needs validation to verify its reliability in predicting airflow for any specific case, in preliminary assessments it is assumed that the accuracy of this turbulence model and CFD code is acceptable. The following boundary conditions were applied : power-law wind velocity profile with exponent $\alpha=0.22$; zero external ambient pressure; no heat transfer; structured grid distribution: 106, 72, and 39 in the $x$-, $y$ - and $z$-axes, respectively; Hybrid convection schemes; equilibrium Logarithmic wall-function, SIMPLES algorithm [26], global convergence criteria of 0.01 , converged iteration of around 3500 . Average wind velocity of $1 \mathrm{~m} / \mathrm{s}$ at height of $1.1 \mathrm{~m}$ in the in-situ measurement was adopted in all simulations. All windows were assumed to be opened while doors were closed, reflecting normal operating conditions of the house. Urban context was included into the model by adding neighbouring houses and creating a street canyon. Airflow field in the living room, retail shop and courtyard in five cases as well as their simulation results were examined as shown in Table 9.

Fig. 11. Indoor illuminance compared with Building code (15 h, 16th December).

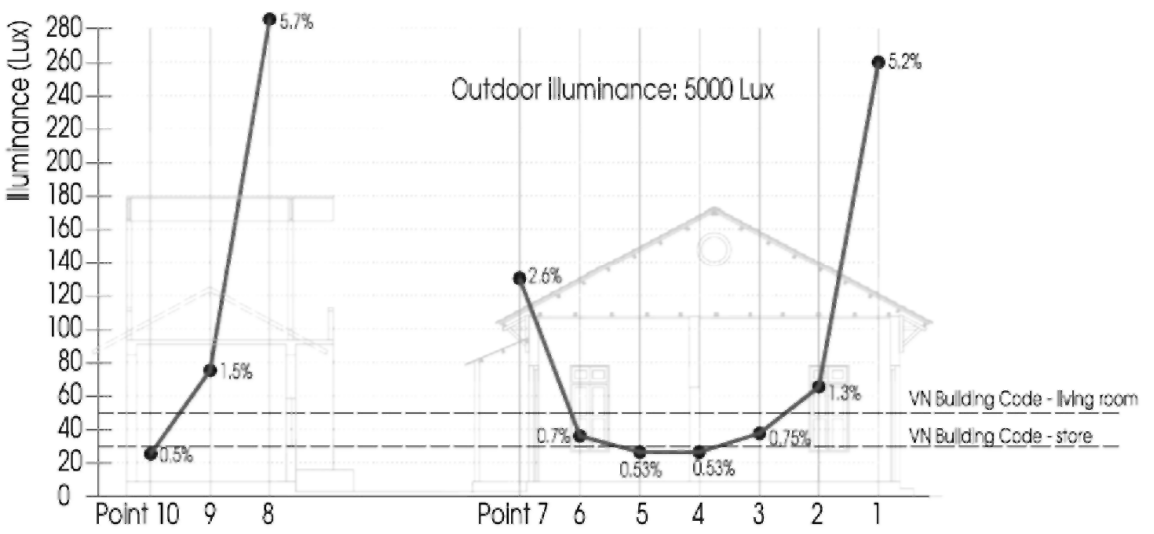


Table 9 Characteristics of airflow field through the model.

\begin{tabular}{|c|c|c|c|c|c|c|c|c|c|}
\hline \multirow[t]{3}{*}{ Case } & \multirow[t]{3}{*}{ Wind angle of attack ${ }^{b}$} & \multicolumn{2}{|c|}{ Ventilation flow rate $\left(\mathrm{m}^{3} / \mathrm{s}\right)$} & \multicolumn{6}{|c|}{$\begin{array}{l}\text { Average wind velocity on working plane } 1.1 \mathrm{~m} \text { above } \\
\text { floor level }(\mathrm{m} / \mathrm{s})\end{array}$} \\
\hline & & \multirow[t]{2}{*}{ Living room } & \multirow[t]{2}{*}{ Retail shop } & \multicolumn{2}{|c|}{ Living room } & \multicolumn{2}{|c|}{ Retail shop } & \multicolumn{2}{|c|}{ Courtyard } \\
\hline & & & & Velocity & STDV $^{\mathrm{a}}$ & Velocity & STDV $^{\mathrm{a}}$ & Velocity & STDV $^{\mathrm{a}}$ \\
\hline$\overline{\mathrm{A}}$ & $0^{\circ}$ & 0.264 & 0.147 & 0.047 & 0.036 & 0.022 & 0.030 & 0.202 & 0.065 \\
\hline B & $30^{\circ}$ & 0.204 & 0.229 & 0.075 & 0.077 & 0.079 & 0.082 & 0.234 & 0.084 \\
\hline $\mathrm{C}$ & $45^{\circ}$ & 0.188 & 0.258 & 0.070 & 0.083 & 0.132 & 0.130 & 0.234 & 0.090 \\
\hline $\mathrm{D}$ & $90^{\circ}$ & 1.272 & 1.567 & 0.331 & 0.219 & 0.300 & 0.285 & 0.324 & 0.173 \\
\hline$E^{c}$ & $90^{\circ}$ & 1.370 & 1.619 & 0.366 & 0.253 & 0.323 & 0.304 & 0.181 & 0.152 \\
\hline
\end{tabular}

${ }^{\mathrm{a}}$ Standard deviation.

${ }^{\mathrm{b}}$ Prevailing wind direction of Hanoi in summer $\left(90^{\circ}\right.$ wind direction is perpendicular to the front façade).

${ }^{c}$ Side corridor was closed by the front door.

In cases $\mathrm{A}, \mathrm{B}$, and $\mathrm{C}$, ventilation flow rates were low due to the "slide-effect" caused by inertial force of the wind and the row house (wind slides on building surface without entering the room). This detailed CFD analysis found that in these cases, courtyard-facing windows sometimes played a more important role than street-facing windows did. The "slide-effect" can be reduced by providing each of two front windows with vertical wing walls. Case D and E had significantly higher flow rates since "slide-effect" did not occur. Standard deviation is shown in Table 9 as well as that wind motion in the Living room was more homogeneous than that in the Retail shop; and outdoor wind was generally more homogeneous than its indoor counterpart.

3.5.1.1. Effects of side corridor. Comparison between case D (side corridor open) and case E (side corridor closed) shows that ventilation flow rate and average indoor velocity increased noticeably when the side corridor was closed (case E). Another effect was that average velocity in the courtyard dropped significantly in this case. These phenomena can be explained by employing the principle of static pressure drop. Fig. 12 illustrates pressure and velocity filed in these two cases. It is clear that case E had a larger static pressure drop between the windward and leeward wall than that of case D. According to Bernoulli's equation of flow rate $(Q=$

$C_{d} A u_{\text {ref }} \sqrt{ } \Delta C_{p}$; where $\Delta C_{P}$ is mean pressure coefficient across the openings), this high pressure drop leads to higher flow rate in case E. Average velocity in the courtyard in case D $(0.324 \mathrm{~m} / \mathrm{s})$ was, in contrast, far higher that that of case $\mathrm{E}(0.181 \mathrm{~m} / \mathrm{s})$, proving that the side corridor played the role of a wind tunnel which induced more wind into the courtyard.

Since natural ventilation conditions in the front and back part of this house is a function of wind conditions in the courtyard, the side corridor and the courtyard are a good way to control natural ventilation. Closing the side corridor gives better ventilation in the front part while opening the side corridor improves wind induced ventilation in the back part.

3.5.1.2. Comparison with standard and code. ASHRAE standard 62.1 [27] recommends that in residential facilities Air change rates should be higher than $0.35 \mathrm{ACHs}$ and $7.51 / \mathrm{s}$. person to ensure indoor air quality. Flow rates shown in Table 9 were far higher than these requirements (minimum air change rate occurred in case $\mathrm{A}$ and was $3.01 \mathrm{ACHs}$ ). However, the average indoor wind velocity of case $\mathrm{A}, \mathrm{B}$ and $\mathrm{C}$ were lower than the minimum wind speed $(0.2 \mathrm{~m} / \mathrm{s}[20])$ needed to improve human thermal sensation.

\subsubsection{Simulation of shading effect by solar shading devices}

Shading effectiveness of the shading devices was examined by using the solar tool embedded in Ecotect analysis ${ }^{\circledR}$ software [28]. Three cases are presented in Fig. 13. Case B reflects the current context in which the house exists whereas case $\mathrm{A}$ and case $\mathrm{C}$ are the control case and comparative case, respectively.

Percentages of the shaded area on different vertical surfaces are compared in Fig. 14. It can be seen that in the current context (case B), the house is currently suitably protected by its shading system since all walls achieved very high shaded percentages (over $90 \%$ ) in summer and much of the sunlit area in winter. In its previous context (case C), the shading system also performed well with over $80 \%$ average shading area in summer. Certainly, case A performed worst among these cases although north and south walls were protected well in summer. In brief, the shading system of the house almost satisfies the shading requirement, especially in the current context. 
Fig. 12. Distribution of static pressure and time-averaged velocity in case D with side corridor opened (above) and case $E$ with side corridor closed (below).

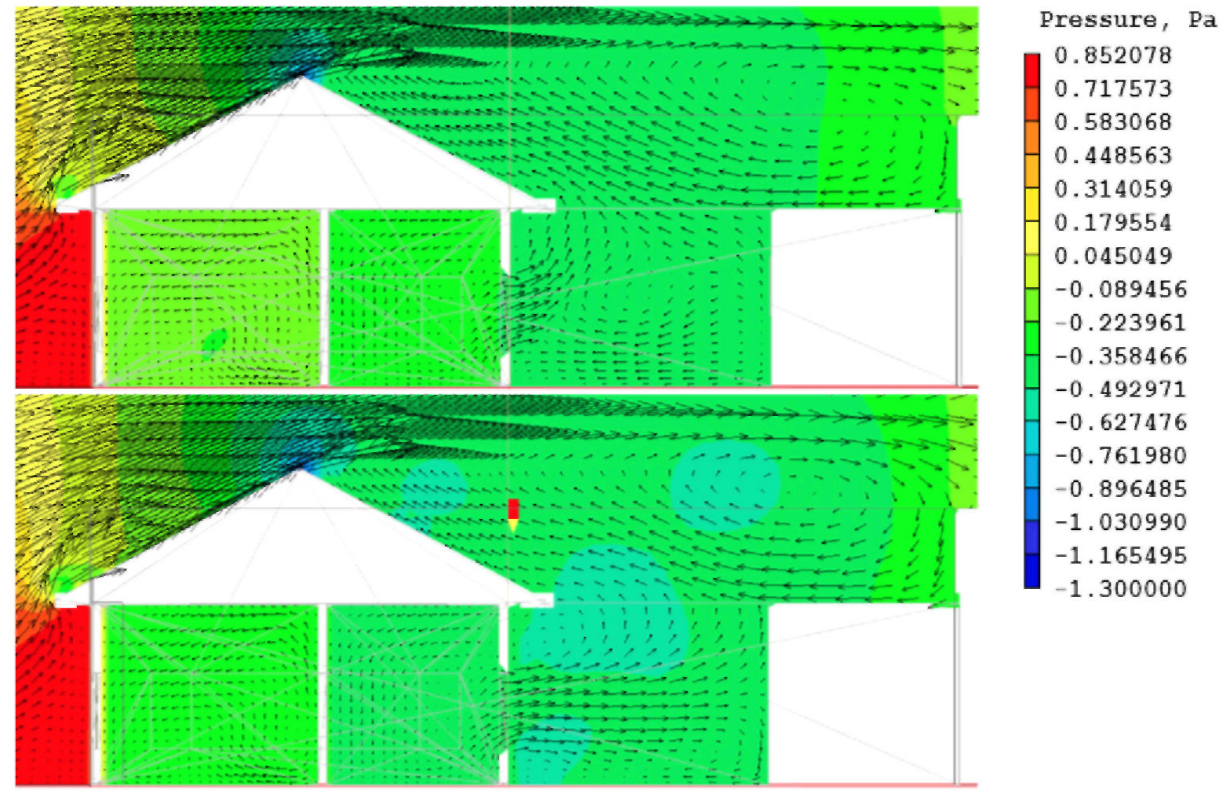

Fig. 13. Three cases in the study of solar shading effectiveness (14 h; 11th July).

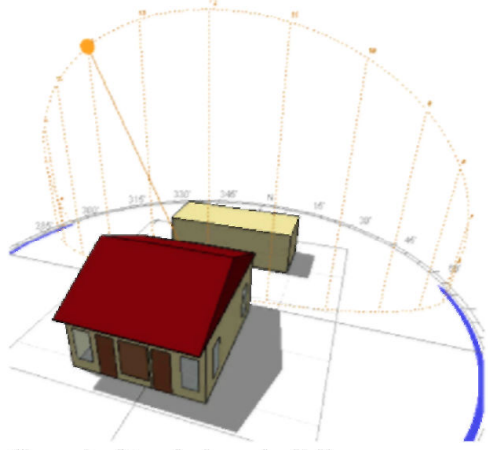

Case A: Stand alone building

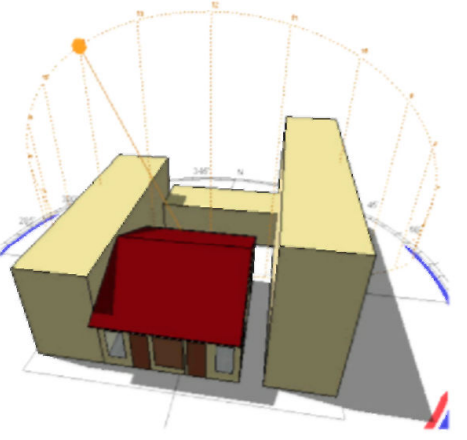

Case B: Building in current context

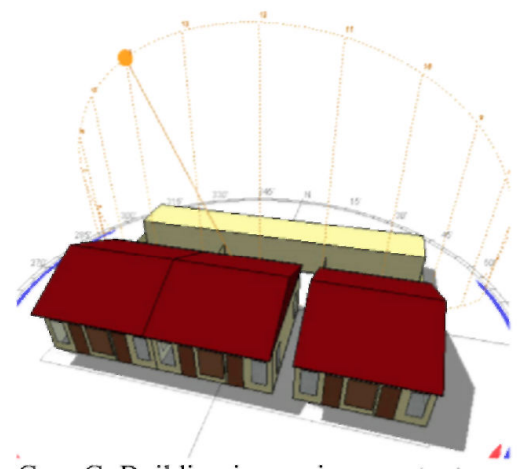

Case C: Building in previous context

\subsubsection{Simulation of thermal performance}

This study employed COMFIE [29] thermal simulation tool developed by "Centre d'Énergétique de l'École des Mines de Paris". This software requires information regarding global characteristics of the buildings in question: materials, composition, building finishes, ventilation schedules, surrounding conditions and so forth. COMFIE's performance was validated by Peuportier [30] by comparing simulation results with those of similar tools like DOE2, TRNSYS, TAS, SIMULA, CODYBA, confirming COMFIE successfully predicted the building thermal environment. However, the calibration procedure for this case which helps to improve the accuracy of simulation results was overlooked due to lack of experimental details. Therefore, the following scenarios were assumed: operating scheme reflects the activity of a typical Vietnamese family (maximum of 4 occupants during night time); three natural ventilation strategies (night, daytime and full-day ventilation) with different flow rates were separately applied for summer, winter and the mild season using a maximum flow rate of $0.258 \mathrm{~m}^{3} / \mathrm{s}$ obtained from the CFD simulation; the attic was ventilated at $1 \mathrm{ACH}$ during daytime and $0.5 \mathrm{ACH}$ during night time; the average internal heat gain was $25 \mathrm{~W} / \mathrm{m}^{2}$ and varied according to the house's occupancy; the weather data was exploited from a Typical Meteorological Year (TMY) weather file of Hanoi, then converted into Test Reference Year (TRY) format for COMFIE. All building parameters were reproduced in the model as shown in Fig. 15 and Appendix. 
Temperature variation during a year shown in Fig. 16 shows that indoor temperature was relatively stable, regardless of the fluctuation of outdoor temperature. However, the house failed to protect indoor environment from extreme outdoor conditions although these conditions did not last very long (see highlighted points in Fig. 16). For the rest of the year, the indoor environment was almost thermally acceptable.

Thermal comfort in the living room was examined by plotting hourly temperatures on an adaptive comfort model proposed by de Dear and Brager [31]. The optimum comfort temperature underlined in this model is as follows:

$$
T_{\text {comf }}=0.31 T_{\mathrm{a} ; \text { out }}+17.8
$$

where: $T_{\text {comf }}$ is comfort temperature and $T_{\mathrm{a} \text {;out }}$ is mean outdoor dry bulb temperature.

The plotting result in Fig. 17 a shows that $58.21 \%$ of the total time was found to be thermally acceptable, corresponding with $90 \%$ acceptability. About $70 \%$ of the uncomfortable period dropped into the cold zone, showing that the house needs further thermal insulation against the cold in free running mode. Fig. $17 \mathrm{~b}$ shows that there was only $6 \%$ of the total time in which indoor temperature exceeded $31{ }^{\circ} \mathrm{C}$, proving that the house performed better in hot weather. According to ISO 7730 [19] and ASHRAE standard 55 [20], this warm sensation (about $2{ }^{\circ} \mathrm{C}$ higher than comfort temperature) can be completely eliminated by a wind speed of 0.6 $\mathrm{m} / \mathrm{s}$, e.g. created by a ceiling fan. This finding does not coincide with that in Section 3.4, indicating that a shortterm in-situ survey cannot always provide an overview of a buildings' performance.

Fig. 14. Shading effectiveness on the hottest day - 11th July (above) and monthly average shading percentage of the vertical façades (below).
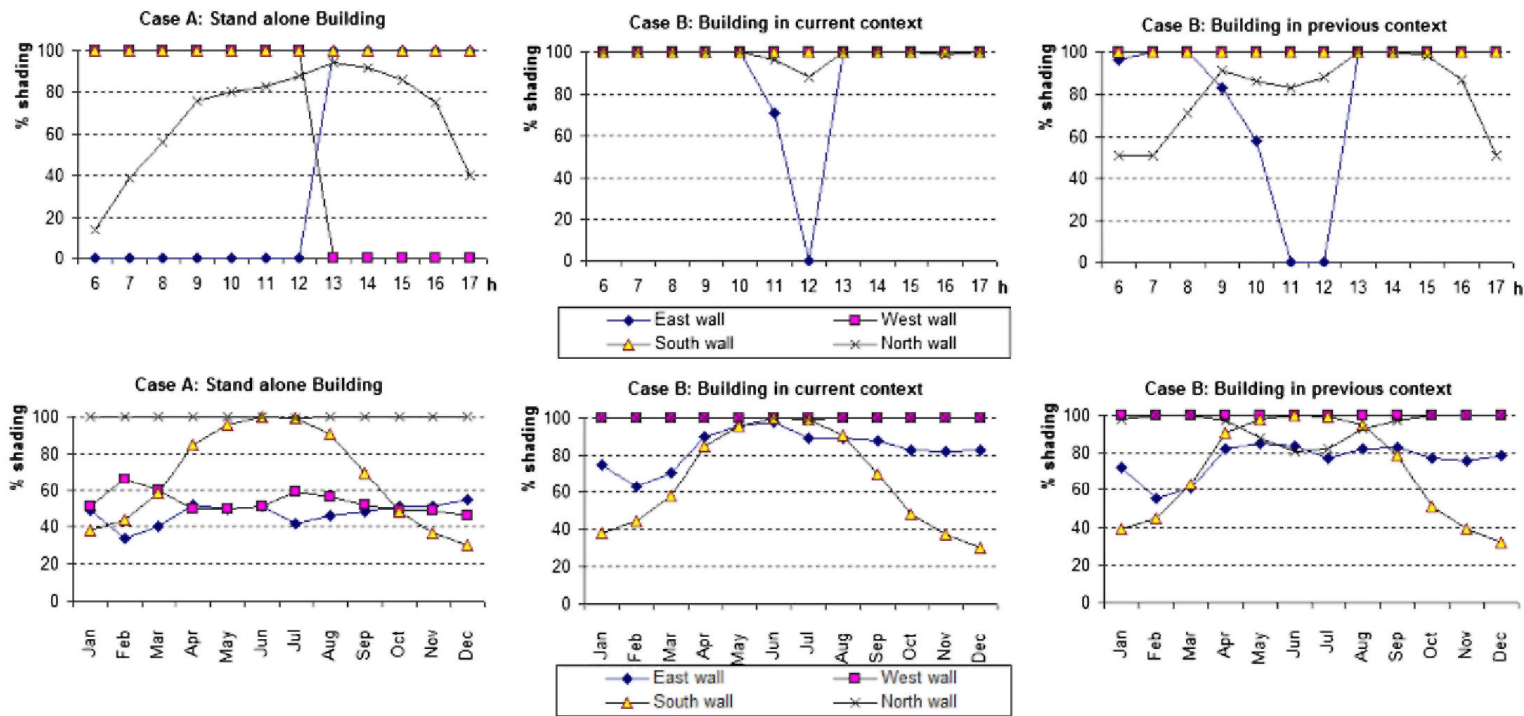

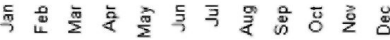

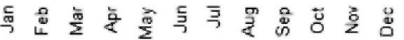


Fig. 15. Building model for the simulation on thermal performance.
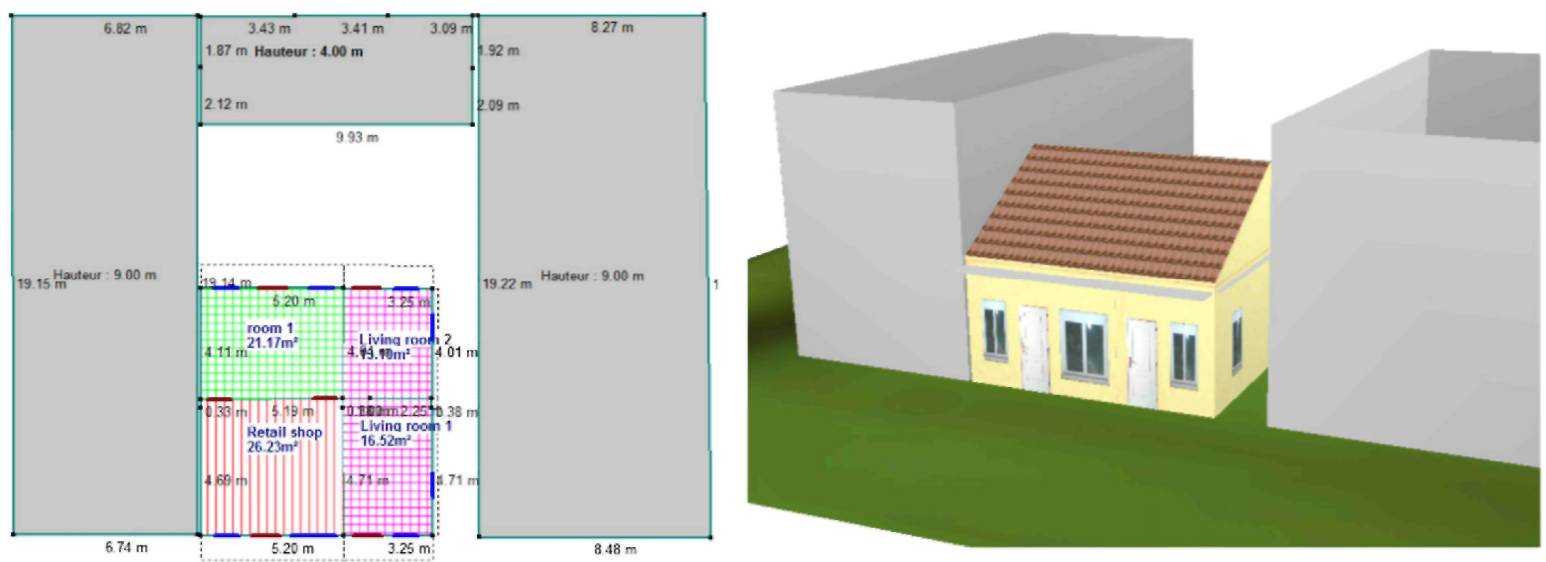

\subsection{Step 6: discussion and conclusions}

This study thoroughly assessed the design principles employed in simple, durable and eco-friendly vernacular dwellings in Vietnam and their effectiveness by qualitatively and quantitatively assessing their performance. The new approach launched in this study to evaluate vernacular architecture proves to be effective and adequate and may be employed in the research of vernacular housing in other regions. Nevertheless, necessary modifications would be strongly recommended due to the differences in climate, geographical features and so forth.

The results of this study clearly indicate that not all vernacular buildings have perfect building physics. Through this study, the advantages and disadvantages of these buildings were thoroughly investigated, with the aim to effectively exploit their positive attributes for current developments. The evaluation of a vernacular building should employ suitable objective methods; otherwise the process leads to incorrect or inaccurate findings as described in Section 3.5.3. Since the weather might change from day to day, in some cases short-term in-situ measurement cannot give an accurate overview of building performance. It would be better to combine shortterm in-situ measurements with other long-term prediction tools, such as building simulation.

Fig. 16. Temperature variation in the living room over one year.

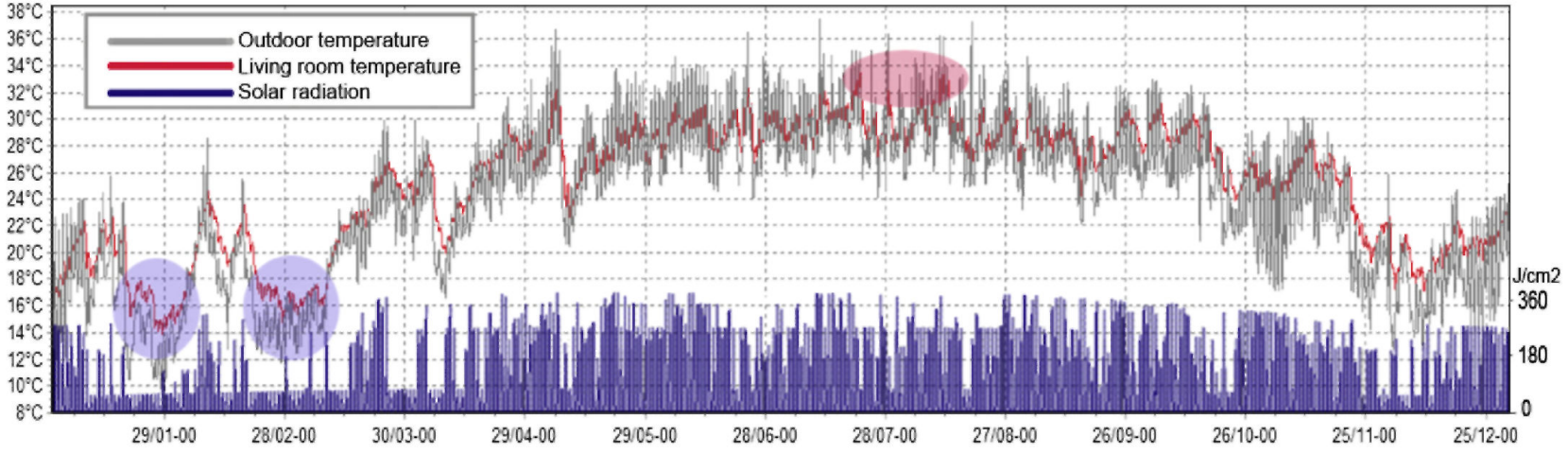


Fig. 17. Hourly plot of air temperature on an adaptive comfort model (left) and cumulative distribution of indoor temperature (right) in the living room over one year.
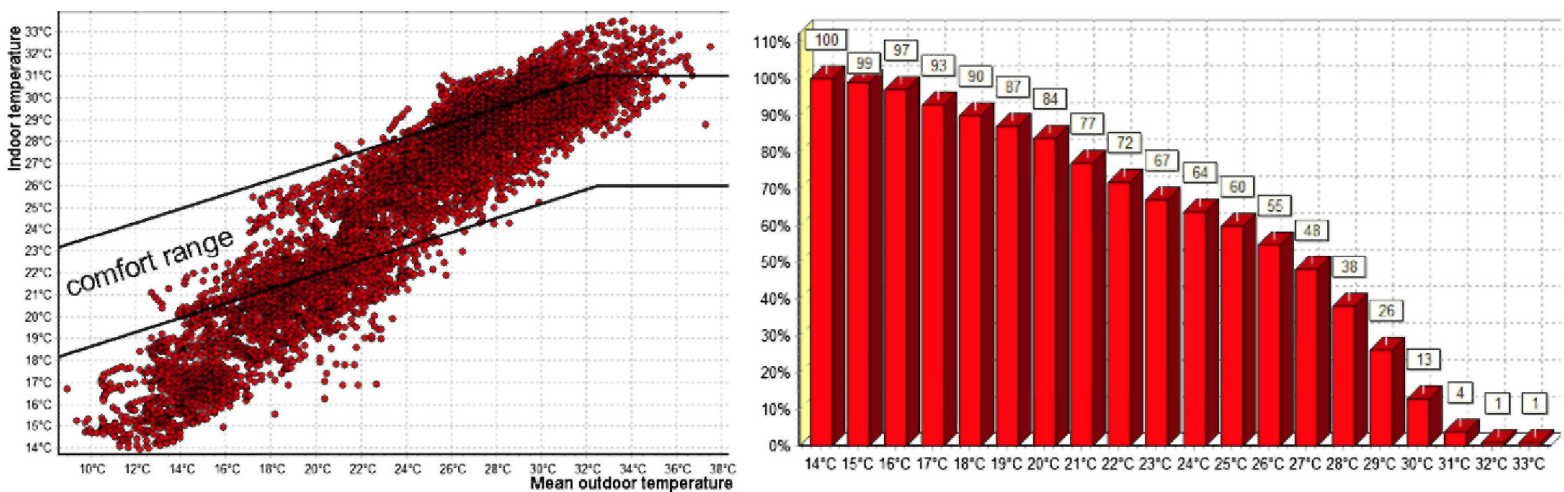

Generally, vernacular housing in Vietnam has adapted fairly well to climatic conditions in different locations by using low-energy design principles that basically ensure human comfort and health. Natural ventilation, building orientation - building shape and solar shading were the strategies most commonly employed whereas earth cooling and high thermal mass seemed inappropriate. Although thermal insulation was not used in the six investigated dwellings, but the above - mentioned analyses suggested that thermal insulation will improve indoor thermal comfort during the cold weather in the Northern areas of Vietnam. The survey on a house in an urban area showed that the shading devices performed quite well, but the distribution and configuration of the openings should be adjusted to improve natural lighting and ventilation. Building courtyard played a significant role on ventilation flow rate of the rooms facing the courtyard.

In the relatively severe climate of Vietnam, relying entirely on traditional design strategies to maintain thermal comfort is not completely possible. Therefore, under extreme conditions the building would benefit from lowenergy mechanical systems, such as mechanically assisted ventilation, evaporative cooling, passive solar heating... or occupants' adaptive responses such as clothing insulation, activities, opening controls and the use of fans.

The present study has limitations as the quantitative assessment of only one house was carried out. A larger investigation is therefore needed. Besides, further study to include comparative assessments between vernacular and more modern architecture is necessary to better evaluate their performance and provide recommendations for sustainable housing design in Vietnam.

In conclusion, this study has emphasised the importance of climate conscious appropriate building design for the living environment without excessive use of natural resources. Vernacular housing in Vietnam is evidence that humans can live in harmony with nature, confirming the need to preserve vernacular architecture there.

\section{Acknowledgements}

This study was financially supported by the Ministry of Education and Training of Vietnam (Grant $\mathrm{N}^{\circ} 624 / \mathrm{QD}^{\circ}$ BGDDT: 9th Feb. 2010) and partly by Wallonie Bruxelles International (Grant N²3478/AMG/BEVN/JP/jp). We would like to thank the Centre for the Preservation and Restoration of Hoian city and the Centre for Heritage and Tourism of Quangnam province for their support and input data. The authors also appreciate all reviewers' comments, the initial help of Anne Françoise Marique and other friends. 


\section{Appendix}

Compositions of building enclosures used in the thermal simulation units

\begin{tabular}{lcc}
\hline Characteristic & Nomenclature & Unit \\
\hline Thickness & $E p$ & $\mathrm{~cm}$ \\
Conductivity & $\lambda$ & $\mathrm{W} /(\mathrm{m} \mathrm{K})$ \\
Density & $D$ & $\mathrm{~kg} / \mathrm{m}^{3}$ \\
Specific heat capacity & $C_{p}$ & $\mathrm{Wh} /(\mathrm{kg} \mathrm{K})$ \\
Coefficient of surface transmission & $U$ & $\mathrm{~W} /\left(\mathrm{m}_{2} \cdot \mathrm{K}\right)$ \\
Thermal resistance & $R$ & $\left(\mathrm{~m}^{2} \cdot \mathrm{K}\right) / \mathrm{W}$ \\
\hline
\end{tabular}

List of composition used.

\begin{tabular}{|c|c|c|c|c|c|c|}
\hline Simple composition & Traditic & floor & & & & \\
\hline Component & $E p$ & $\lambda$ & $\bar{D}$ & $C_{P}$ & $U$ & $R$ \\
\hline Ramped earth & 25.0 & 0.850 & 2000 & 0.280 & 0.29 & 3.40 \\
\hline Broken brick with mortar & 10.0 & 1.050 & 1700 & 0.256 & 0.10 & 10.50 \\
\hline Mortar & 3.0 & 1.150 & 2000 & 0.233 & 0.03 & 38.33 \\
\hline Tile $200 \times 200 \times 20$ & 2.0 & 0.143 & 790 & 0.222 & $\begin{array}{l}7.14 \\
7.56\end{array}$ & $\begin{array}{l}0.14 \\
0.13\end{array}$ \\
\hline Simple composition & Tiled ro & & & & & \\
\hline Component & $E p$ & $\lambda$ & $D$ & $C_{P}$ & $U$ & $R$ \\
\hline Fired clay roof tile & 2.5 & 0.042 & 1700 & 0.220 & 1.67 & 0.60 \\
\hline Light timber & 0.5 & 0.150 & 500 & 0.333 & $\begin{array}{l}0.03 \\
1.70\end{array}$ & $\begin{array}{c}30.00 \\
0.59\end{array}$ \\
\hline Simple composition & Woode & eiling & & & & \\
\hline Component & $E p$ & $\lambda$ & $D$ & $C_{P}$ & $U$ & $R$ \\
\hline Cellulose insulation & 4.0 & 0.045 & 55 & 0.390 & 0.89 & 1.13 \\
\hline Light timber & 2.0 & 0.150 & 500 & 0.333 & $\begin{array}{l}0.13 \\
1.02\end{array}$ & $\begin{array}{l}7.50 \\
0.98\end{array}$ \\
\hline Simple composition & $220 \mathrm{mn}$ & rick wa & & & & \\
\hline Component & $E p$ & $\lambda$ & $D$ & $C_{P}$ & $U$ & $R$ \\
\hline Mortar & 2.0 & 1.150 & 1700 & 0.278 & 0.02 & 57.50 \\
\hline Cruel brick of $10 \mathrm{~cm}$ & 10.0 & 0.480 & 690 & 0.250 & 4.76 & 0.21 \\
\hline Void $1.1-1.3 \mathrm{~cm}$ & 1.2 & 0.080 & 1 & 0.340 & 6.66 & 0.15 \\
\hline Cruel brick of $10 \mathrm{~cm}$ & 10.0 & 0.480 & 690 & 0.250 & 4.76 & 0.21 \\
\hline Mortar painted by lime & 2.0 & 0.700 & 1400 & 0.280 & $\begin{array}{c}0.03 \\
16.23\end{array}$ & $\begin{array}{c}35.00 \\
0.06\end{array}$ \\
\hline
\end{tabular}

Doors and window.

\begin{tabular}{lc}
\hline Name & $U$ value \\
\hline Exterior wooden doors & 3.03 \\
Wooden panel window & 3.68 \\
Two-layer French window & 1.70 \\
Interior wooden door & 2.40 \\
\hline
\end{tabular}

Scenarios of the coefficient of albedo.

\begin{tabular}{lr}
\hline Name & All year \\
\hline Concrete & 0.2 \\
\hline
\end{tabular}




\section{Surface conditions.}

\begin{tabular}{lcc}
\hline Name & Emissivity & Absorptivity \\
\hline Red Brick & 0.92 & 0.68 \\
Cement & 0.88 & 0.60 \\
Smooth white colour & 0.85 & 0.25 \\
White mixture of lime and water (dried) & 0.80 & 0.3 \\
\hline
\end{tabular}

\section{References}

[1] Vietnam Ministry of constructioaln: Proceeding of the seminar "Effective and economic usage of energy and resources in building sector". (Hanoi); 2010

[2] Coch H. Bioclimatism in vernacular architecture. Renewable and Sustainable Energy Reviews 1998;2(1-2):67-87.

[3] Dili AS, Naseer MA, Varghese TZ. Passive control methods of Kerala traditional architecture for a comfortable indoor environment: comparative investigation during various periods of rainy season. Building and Environment 2010;45: 2218-30.

[4] Cañas I, Martin S. Recovery of Spanish vernacular construction as a model of biodimatic architecture. Building and Environment 2004;39:1477-95.

[5] Vissilia AM. Evaluation of a sustainable Greek vernacular settlement and its landscape: architectural typology and building physics. Building and Environment 2009;44:1095-106.

[6] Manioğlu G, Yılmaz Z. Energy efficient design strategies in the hot dry area of Turkey. Building and Environment 2008;43:1301-9.

[7] Yoshino H, Hasegawa K, Matsumoto S. Passive cooling effect of traditional Japanese building's features. International Journal of Management of Environmental Quality 2007;18-5:578-90.

[8] Ministry of Construction of Vietnam. Vietnam building code 2009-QCVN 02: 2009/BXD - natural physical \& climatic data for construction. Hanoi; 2009.

[9] Tran TQH. A study on the history of Viet's traditional timer houses in Vietnam. Ph.D thesis. Tokyo Metropolitan University; 2005.

[10] Hammond G, Jones C. Inventory of carbon and energy, version 1.6a. The University of Bath; 2008.

[11] Berge B. The ecology building materials. Oxfords, UK: Architectural Press; 2001 [in English].

[12] Spence RJS, Cook DJ. Building materials in developing countries. UK: John Wiley \& Sons; 1983.

[13] Walker R. Density of materials. Available on http://www.simetric.co.uk [accessed 07.10.10]

[14] Bui QB and Morel JC. Assessing the anisotropy of rammed earth. In: Proceedings of the 11th international conference on nonconventional materials and technologies (Nocmat 2009). (Bath, UK); 2009.

[15] International Organization for Standardization. Ergonomics of the thermal environment - Instruments for measuring of physical quantities. ISO 7726-1998; 1998. Geneva.

[16] Ministry of Construction. TCXD 29:1991: Natural illumination in civil building-design standard; 1991. Hanoi.

[17] Kubota T, Toe Hooi Chyee D, Ahmad S. The effects of night ventilation technique on indoor thermal environment for residential buildings in hot-humid climate of Malaysia. Energy and Buildings 2009;41:829-39.

[18] de Dear RJ. Thermal prediction calculator. Available at http://web.arch.usyd. edu.au [accessed 12.11.10]

[19] International Organization for Standardization. Ergonomics of the thermal environment - analytical determination and interpretation of thermal comfort using calculation of the PMV and PPD indices and local thermal comfort criteria. ISO 7730-2005; 2005. Geneva.

[20] ASHRAE standard 55-2004. Thermal environmental conditions for human occupancy. Atlanta. GS: ASHRAE, Inc; 2004.

[21] Brager GS, de Dear RJ. A ASHRAE standard for natural ventilation. ASHRAE Journal; Oct 2000 [version: reprint with permission].

[22] Fanger PO, Toftum J. Extension of the PMV model to non-air-conditioned buildings in warm climates. Energy and Buildings 2002;34:533-6. 
Published in: Building \& Environment 46 (2011) 2088-2106

Status: Postprint (Author's version)

[23] Gebremedhin KG, Wu BX. Characterization of flow field in a ventilated space and simulation of heat exchange between cows and their environment. Journal of Thermal Biology 2003;28(4):301-19.

[24] Gloria Gomes M, Rodrigues AM, Mendes P. Experimental and numerical study of wind pressures on irregular-plan shapes. Journal of Wind Engineering and Industrial Aerodynamics 2005;93:741-56.

[25] Nguyen AT, Reiter S. The effect of ceiling configurations on indoor air motion and ventilation flow rates. Building and Environment $2011 ; 46: 1211-22$

[26] Spalding DB. The phoenics encyclopedia. Available from, http://www.cham. co.uk/phoenics/d_polis/d_enc/encindex.htm; 2009 [accessed 20.11.10].

[27] ASHRAE standard 62.1-2004 Ventilation for acceptable indoor air quality. Atlanta. GS: ASHRAE, Inc; 2004.

[28] Autodesk Inc. Ecotect analysis 2011 (educational version). Available at www. students.autodesk.com [accessed 01.06.10]

[29] Izuba energies. Pleiades-comfie software. Available at http://www.izuba.fr [accessed 07.04.10]

[30] Peuportier B. Bancs d'essais de logiciels de simulation thermique. Journée Thématique SFT-IBPSA Mars; 2005.

[31] de Dear RJ, Brager SG. Thermal comfort in naturally ventilated buildings: revisions to ASHRAE Standard 55. Energy and Buildings 2002;34: 549-61. 